\title{
Investing near the National Security Black Hole
}

\begin{abstract}
Ji Li*
Multinational corporations dominate the global economy. Their aggressive business expansion has led to occasional conflicts with some sovereign governments' core interests. The most irreconcilable one is probably between foreign direct investments by multinationals and the need of sovereign states to safeguard their national security. This article empirically explores the tension in its most manifested case, i.e., the reactions of China-based multinationals to the highly confidential national security review system of the United States, also known as the Committee on Foreign Investment in the United States ("CFIUS") review. I find that, contrary to conventional wisdom, most Chinese investors know little about CFIUS. The majority of those who have some knowledge about it consider the process politicized and non-transparent. A minority reported to have abandoned contemplated investments in the United States due to concerns with CFIUS. Variations in the perception and the reactions of the China-based multinationals generally turn on their government ownership, sectoral sensitivity, and investment size. In addition, the recent landmark decision in Ralls v. CFIUS has a significant impact on the investors' perception of the system, but has not altered their filing behavior. The findings make several important theoretical and policy contributions.
\end{abstract}

Introduction 2

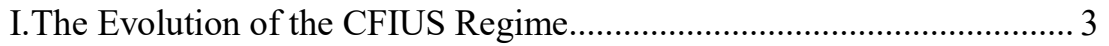

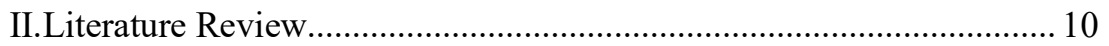

III.To File or Not to File? - The Foreign Investor's Decision Tree .......... 13

A. Pre-Ralls Calculation ............................................................... 15

B. The D.C. Circuit Decision in Ralls Has Changed the

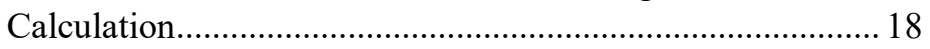

IV.Chinese Investments under the CFIUS Regime ..................................20

A. Chinese Investments in the United States ..................................20

B. The Surveys of Chinese Companies in the United States......... 21

C. Empirical Overview of the Survey Data on Chinese Investors

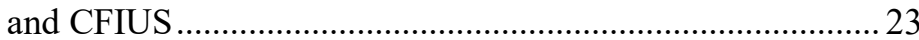

DOI: https://dx.doi.org/10.15779/Z38FQ9Q496

* Associate Professor, Rutgers Law School; J.D. Yale Law School; Ph.D. Northwestern University; email: ji.li@law.rutgers.edu. The author would like to thank Stuart M. Benjamin, Jim Cox, Adam Chilton, Stuart Deutsch, Douglas Eakeley, Taja-Nia Henderson, David Noll, John Leubsdorf, Sabrina Safrin, Reid Weisbord, Huyue Zhang, Wei Zhang, and other participants of the 11th Annual Conference on Empirical Legal Studies (CELS) at Duke Law School and the faculty colloquium at Rutgers Law School. 
1. Consideration and Filing with CFIUS ..............................23

2. Reliance on U.S. Lawyers.............................................. 25

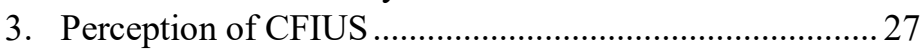

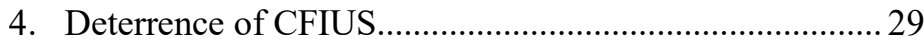

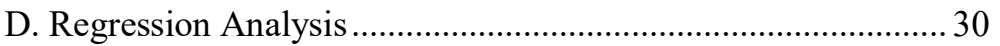

1. Considering CFIUS Review when Investing in the United States 30

a. Dependent Variable...................................................... 31

b. Independent and Control Variables............................... 31

2. Size and Sector: The Most Important Factors for Filing with CFIUS

3. Additional Judicial Scrutiny Aids Perception of the CFIUS

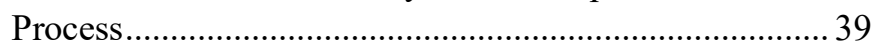

V.Contributions and Limitations ................................................................ 42

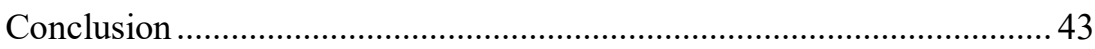

\section{INTRODUCTION}

Multinational corporations reign over the global economy. They conquer with direct investments, and most governments yield to their demands such as heightened property rights protection, favorable tax rates, discounted utilities charges, and free land use. However, almost all sovereign states would mandate that foreign investments not impair their national security. On its face, this threshold should be easy to cross. The vast majority of multinationals seek mainly to maximize profit and would avoid taking actions that threaten the security of a sovereign state. But one easily notices the intractable problem of defining the scope and substance of national security. "Like beauty, [the concept] is very much in the eyes of the beholder." For instance, a takeover of a bankrupt telecommunications company by a foreign firm, well-intentioned in the eyes of the managers, may be viewed by the local government as posing a critical security threat. Tensions between maintaining an open investment market and safeguarding national security inevitably grow as foreign investments aggressively expand worldwide. Nowhere else are the tensions more acute and evident than those between soaring Chinese foreign direct investments ("FDI") and U.S. national security.

While the world's two largest economies have been integrating at an unprecedented rate, their governments continue to harbor deep distrust of each other. Reluctant to change its long-standing open market policy simply in

1. Brandt J. C. Pasco, United States National Security Reviews of Foreign Direct Investment: From Classified Programmes to Critical Infrastructure, This is What the Committee on Foreign Investment in the United States Cares About, 29 ICSID ForEIGN INV. L. J. 350, 355 (2014). 


\section{Investing near the National Security Black Hole}

response to surging investments from China, the U.S. government has been relying on a variety of regulatory institutions to mitigate the potential security risk. Of these institutions, the Committee on Foreign Investment in the United States ("CFIUS") has caught the most attention. The emerging literature on CFIUS, while shedding some light on the highly confidential and discretionary mechanism that has been likened to a "legal black hole," has yet to explore how foreign investors react to the CFIUS process. This study fills this major gap by empirically investigating the perceptions and reactions of Chinese companies in the United States.

The article is organized as follows. Section I briefly describes the evolution of the CFIUS regime along with the trend of foreign investments in the United States. It highlights the significant changes in the rules and the tightening of the scrutiny as a result of surging investments from countries that are not U.S. allies. Section II then presents an overview of the literature on CFIUS and points out both the insights and the gaps. Next, Section III analyzes, using a simplified model, the calculation of rational foreign investors with regard to the filing of a notice with CFIUS. Section IV describes the surveys, presents a selected overview of the data, and conducts statistical tests on three topics central to the ongoing debate about the CFIUS system. The test results indicate that Chinese investors react rationally to the regime and view it more positively after the Ralls decision that to certain extent brought the secretive administrative regime under judicial review. Section V discusses the contributions of this article such as providing the first-ever empirical study of how foreign investors react to the CFIUS review.

\section{The EVOLUTION OF THE CFIUS REGIME}

This section reviews the history of the CFIUS regime and its recent changes caused by the D.C. Circuit decision in Ralls v. CFIUS, which held the Committee's treatment of a Chinese investment violated the investor's constitutional right to due process. ${ }^{2}$ Legal restraints on foreign investment in the United States for national security concerns can be traced back to World War I. Enacted in 1917, the Trading with the Enemy Act ("TWEA") gave the President broad powers to act, in times of war or national emergency, against foreigncontrolled businesses in the United States. ${ }^{3}$ Following the war, Congress passed additional sector-specific restrictions on foreign investment in radio broadcasting, telecommunications, shipping, oil, and air transport. ${ }^{4}$ These formal laws appeared to be sufficient for safeguarding U.S. assets from foreign investors with sinister intents, until the 1970s when OPEC members poured

2. Ralls Corp. v. Comm. On Foreign Inv. in the U.S. (Ralls II), 758 F.3d 296, 319 (D.C. Cir. 2014).

3. EDWARD D. GRAHAM \& DAVID M. MARCHICK, U.S. NATIONAL SECURITY AND FOREIGN DIRECT INVESTMENT 5 (2006).

4. Id. at xvi. 
substantial capital into the U.S. market. The subsequent political pressure culminated in the creation of CFIUS.

Created in 1975 by an executive order, CFIUS was initially responsible merely for monitoring the impact of foreign investment in the United States and coordinating federal policies. ${ }^{5}$ The agency's institutional evolution since then has been a "crisis-driven development of most economic regulators." In the 1980 s, the surge of investment from Japan and the fear of a fast-growing economic competitor surpassing the United States led to the 1988 "Exon-Florio Amendment" to Title VII of the Defense Production Act of 1950 ("DPA"). The amendment formally authorizes the President to block foreign investment that threatens to impair U.S. national security. ${ }^{7}$

Japan's subsequent economic slowdown eased the collective panic and CFIUS, chaired by the Secretary of Treasury, ${ }^{8}$ took a rather lax attitude towards scrutinizing foreign investments. In the past decade, however, political pressure for heightened scrutiny of foreign investments mounted again due to the rise of China, which was widely perceived as potentially posing a formidable economic and geopolitical challenge, and the war on terrorism. Eventually, a few highprofile acquisition attempts by foreign investors triggered the passage of the Foreign Investment and National Security Act of 2007 ("FINSA"), which amended and codified the CFIUS review process and significantly enhanced congressional oversight. ${ }^{9}$

Under Section 721 of the DPA, as amended by FINSA, the President has the authority to block any "covered transaction," broadly defined as "any merger, acquisition, or takeover ... by or with any foreign person which could result in foreign control of any person engaged in interstate commerce in the United States," 10 that threatens to impair U.S. national security, provided no other existing laws could mitigate the threat. For foreign investors, the uncertainties due to the potential exercise of this broad authority may be lessened and managed by a voluntary filing with CFIUS for review and approval prior to the transaction. In contrast to what many believe, the filing of a notice (by a foreign investor or any other party to a covered transaction) with CFIUS is entirely voluntary despite the national security nature of the regulatory regime. ${ }^{11}$ Only $5 \%$ of all foreign

5. Dustin Tingley et al., The Political Economy of Inward FDI: Opposition to Chinese Mergers and Acquisitions, 8 CHINESE J. INT'L POL. 27, 36 (2015).

6. David Zaring, CFIUS as a Congressional Notification Service, 83 S. CAL. L. REV. 90 (2009).

7. Marc Greidinger, The Exon-Florio Amendment: A Solution in Search of a Problem, 6 AM. U. INT’L L. REV. 111, 112-14 (1991).

8. U.S. DEP'T OF THE TREASURY, COMPOSITION OF CFIUS (2010), http://www.treasury.gov/resource-center/international/foreign-investment/Pages/cfius-members.aspx.

9. Margaret Merrill, Overcoming CFIUS Jitters: A Practical Guide for Understanding the Committee on Foreign Investment in the United States, 30 QUINNIPIAC L. REV. 1, 6 (2011).

10. 50 U.S.C. app. $\S 2170($ a)(3) (2006).

11. 31 C.F.R. $\S 800.401(a)(2011)$. 


\section{Investing near the National Security Black Hole}

investments in the United States go through the process. ${ }^{12}$ Absent a voluntary filing, CFIUS has the right to unilaterally initiate a review of a covered transaction by requiring the foreign investor to file a notice. ${ }^{13}$ Following the receipt of a completed notice, CFIUS has thirty days to review and approve the investment or otherwise initiate a forty-five day investigation. ${ }^{14}$ By the end of the forty-five day period, unresolved issues will be submitted to the President, who must either approve or block the transaction within fifteen days. ${ }^{15}$

Acting as the President's agent, CFIUS's jurisdiction is limited to "covered transactions." CFIUS's mandate is to "conduct an investigation of the effects of a covered transaction on the national security of the United States, and take any necessary actions in connection with the transaction to protect the national security of the United States." 16 To allow maximum executive discretion, Congress did not precisely define the scope of "national security." 17 The current law nonetheless provides a non-exhaustive list of considerations, including investment that impacts "domestic production needed for ... national defense," "United States critical technologies," "long-term requirements for . . critical resources," and "critical infrastructure." 18 In addition, FINSA mandates CFIUS investigation in situations where the covered transaction results in foreign government control or foreign control of U.S. critical infrastructure. ${ }^{19}$ Because of this legal requirement, sizable Chinese multinationals, a significant fraction of which are state-owned, are particularly sensitive to CFIUS investigation. ${ }^{20}$ Finally, CFIUS is not time-barred from opening a review of a covered transaction, ${ }^{21}$ and the law shields the findings and actions of the President from judicial review. ${ }^{22}$

12. Richard A. Chesley \& Daniel M. Simon, Initiating Substantial Uncertainty into an Already Uncertain Process: The Intersection of National Security and Bankruptcy, GLOB. INSIGHT (Mar. 25, 2013), https://www.dlapiper.com/en/us/insights/publications/2013/03/initiating-substantial-uncertaintyinto-an-alrea

13. 50 U.S.C. app. $\S 2170$ (b)(1)(D) (Defense Production Act of $1950 \S 721$, as amended by FINSA).

14. 31 C.F.R. $\S \S 800.502-505(2011)$; 50 U.S.C. app. $\S \S 2170($ b)(2)(C)-(d)(2) (2006). Note that in practice it may take much longer for foreign investors to go through the process as CFIUS gets to determine the application's completeness. The clock starts to run only after the filing is deemed complete. C.f. Jingli Jiang \& Gen Li, CFIUS: For National Security Investigation or for Political Scrutiny?, 9 TEX. J. OIL GAS \& ENERGY L. 67, 97 (2013) (contemplating CFIUS authority to review and dissolve transactions on a retroactive basis more than three years after their completion-a form of "indefinite, retroactive review" which may operate as a stern incentive for otherwise reticent filers).

15. 31 C.F.R. $\S \S 800.506($ b)(l)-(3) (2011); 50 U.S.C. app. $\S 2170(d)(2)(2006)$.

16. 50 U.S.C. app. $\S 2170(\mathrm{~d})(2)(2006)$.

17. Jose W. Fernandez, Lessons from the Trenches, 33 INT'L FIN. L. REV. 44, 44 (2014).

18. 50 U.S.C. app. $\S 2170$ (f) (2006).

19. 50 U.S.C. app. $\S 2170(b)(2)(B)(2006)$.

20. $I d$.

21. Andreas Heinemann, Government Control of Cross-Border M\&A: Legitimate Regulation Or Protectionism? 15 J. INT'L ECON. L. 843, 844 (2012).

22. 50 U.S.C. app. $\S 2170$ (e) (2006). 
From 2008 to 2014,782 notices were filed, ${ }^{23}$ mostly by companies from countries that are considered U.S. allies. The U.K. topped the ranking of source countries until 2012, when it was overtaken by China (see

Figure 1). Since 2012, Chinese investors have accounted for the most notices filed each year. CFIUS rarely rejected properly notified transactions, though foreign investors sometimes "voluntarily" withdrew their notices "in light of a CFIUS determination to recommend that the President suspend or prohibit the transaction". ${ }^{24}$ In addition, preliminary meetings with key officials prior to a transaction also helped cap the number of rejections, as those foreign investors anticipating hostile reactions would have abandoned the deal. ${ }^{25}$ Thus, the published annual data reveals little about the actual impact of the CFIUS process on foreign investment in the United States.

Shrouded in secrecy, the CFIUS review process is a "legal black hole." 26 Yet until recently, no foreign investor had ever challenged a CFIUS action in a U.S. court, likely due to the agency's relatively infrequent intervention, ${ }^{27}$ the underlying national security nature of the process, and the statutory provision clearly constraining judicial review. ${ }^{28}$ But after CFIUS stepped up its scrutiny of foreign investments after FINSA (see Figure 2), and investments originating from China continued to grow exponentially, soaring frictions ensued. CFIUS reviewed a disproportionately high percentage of Chinese acquisitions of U.S. assets, ${ }^{29}$ and more high profile Chinese investments failed due to issues with the CFIUS review. ${ }^{30}$ Eventually, a resourceful Chinese investor threw down the gauntlet and sued CFIUS and President Obama for actions taken against its investment in the United States.

23. 538 notices from 2008 to 2012. U.S. DEPT. OF THE TREASURY, COVERED TRANSACTIONS, WiTHDRAWALS, AND PRESIDENTIAL DECISIONS 2008-2012, http://www.treasury.gov/resourcecenter/international/foreign-investment/Documents/CFIUS\%20Stats\%202008-2012.pdf (last visited Oct. 22, 2014). There were 97 notices filed in 2013 and 147 notices filed in 2014. CFIUS, ANN. REP. TO CONG. (2014).

24. CFIUS, ANN. REP. TO CONG. 22 (2014).

25. Diane Bartz \& Greg Roumeliotis, The Washington Insiders Who Work to Get Chinese Deals Approved, REUTERS (Feb. 25, 2016), http://www.reuters.com/article/us-usa-china-deals-advisors-insightidUSKCNOVX2PX.

26. See, e.g., Christopher M. Tipler, Defining 'National Security': Resolving Ambiguity in the CFIUS Regulations, 35 U. PA. J. INT'L L. 1223, 1243 (2014); see also Joshua C. Zive, Unreasonable Delays: CFIUS Reviews of Energy Transactions, 3 HARV. BUS. L. REV. ONLINE 169 (2013).

27. Zaring, supra note 6 , at 87.

28. 50 U.S.C. app. $§ 2170$ (e) (2006).

29. Friedrich $\mathrm{Wu} \&$ Andreas Bakke Frøystadvåg, China Investment Corporation's Forays into Europe and the United States: Explaining the Different Receptions, 25 J. OF CONTEMP. CHINA 91, 99 (2016).

30. Thilo Hanemann \& Daniel Rosen, Don't Misread Old Tealeaves: Chinese Investment and CFIUS, Rhodium Group (Feb. 24, 2016), http://rhg.com/notes/dont-misread-old-tealeaves-chineseinvestment-and-cfius. 
Investing near the National Security Black Hole

Figure 1: CFIUS-Reported Covered Transactions by Investor's Home Country (2006-2014)

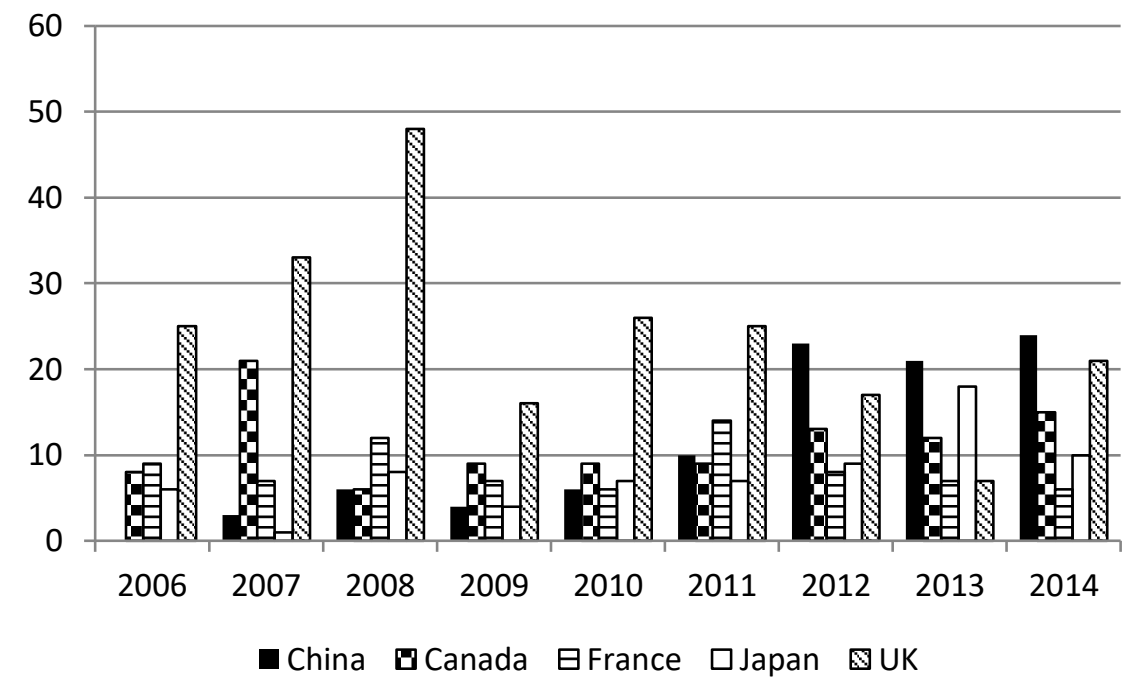

Data source: Annual Reports to Congress (2008-2016) by Committee on Foreign Investment in the United States, available at http://www.treasury.gov/resourcecenter/international/foreign-investment/Pages/cfius-reports.aspx.

In March 2012, Ralls Corporation, a company incorporated in Delaware but owned by two Chinese nationals, purchased four U.S. companies with the intent to develop windfarms on the land they owned in north-central Oregon. ${ }^{31}$ The targeted sites are located in and around the "region of a restricted airspace and bombing zone maintained by the U.S. Navy." 32 Ralls did not file a notice with CFIUS prior to the transaction. Prompted by the U.S. Navy, Ralls subsequently made the filing, and CFIUS determined that the transaction threatened to impair U.S. national security and issued interim mitigation orders restricting Ralls's access to the windfarm sites pending the President's final decision..$^{33}$ The matter was then submitted to President Obama, who concurred that the transaction posed a national security threat and blocked the transaction. Pursuant to the Presidential order, Ralls must divest all its interests in the target U.S. business

31. Ralls Corp. v. Comm. On Foreign Inv. in the U.S. (Ralls II), 758 F.3d 296, 319 (D.C. Cir. 2014).

32. Id. at 304 .

33. Id. at 302 . 
within 90 days; and the sale must be approved by CFIUS. ${ }^{34}$ Due to the onerous conditions, Ralls expected to lose at least $\$ 20$ million. ${ }^{35}$

Throughout the process, Ralls received no explanation and was given no opportunity to rebut any evidence against it. ${ }^{36}$ In response to the actions of CFIUS and later President Obama, Ralls filed a lawsuit claiming, inter alia, the violation of its due process right under the Fifth Amendment. ${ }^{37}$ The District Court initially dismissed most of Ralls's claims as moot or for lack of subjectmatter jurisdiction, ${ }^{38}$ and later tossed out the due process claim as well for failure to state a claim. ${ }^{39}$ Upon Ralls's appeal, the D.C. Circuit surprisingly reversed the lower court's decisions. ${ }^{40}$

The D.C. Circuit rejected the argument that Ralls's due process claim was a nonjusticiable political question as the claim did not "encroach on the prerogative of the political branches," "did not require the exercise of non-judicial discretion," and was "susceptible to judicially manageable standards." 41 The D.C. Circuit decided that Ralls was denied due process as it was neither informed of the nature of the national security concern with the acquisitions or the evidence on which the determination was based, nor allowed an opportunity to rebut. ${ }^{42}$ The D.C. Circuit remanded the case to the District Court with instructions that Ralls be provided access to the unclassified evidence on which the decision was based and an opportunity to respond thereto. ${ }^{43}$ It also instructed the lower court to fully adjudicate several other legal issues raised by the investor. After CFIUS handed over three thousands pages of documents to Ralls, the two parties negotiated an undisclosed settlement, under which Ralls was allowed to sell its interests to desired purchasers. ${ }^{44}$ The settlement, however, left unresolved several important legal issues concerning the CFIUS process such as the boundary of the agency's statutory authority. ${ }^{45}$

34. Ralls Corp. v. Comm. On Foreign Inv. in U.S. (Ralls I), 987 F. Supp. 2d 18, 27 (D.D.C. 2013), rev'd and remanded, 758 F.3d 296 (D.C. Cir. 2014).

35. Jasmine Wang, China Watching Sany U.S. Wind-Farm Case, Minister Chen Says, BLoOMBERG (Mar. 5, 2013), https://www.bloomberg.com/news/articles/2013-03-05/china-watching-sany-u-s-windfarm-case-commerce-minister-says.

36. Ralls II, 758 F.3d at 306.

37. Id. at 315 .

38. Id. at 306 .

39. Id. at 307 .

40. Id. at 309 .

41. Id. at $307-13$.

42. Id. at 325 .

43. Id.

44. Paul Welitzkin, Lawsuit Settlement Seen as Unlikely to Affect CFIUS, CHINA DAILY (Nov. 11, 2015), http://usa.chinadaily.com.cn/epaper/2015-11/06/content_22387282.htm.

45. Briefly, the claims to be fully adjudicated on remand include: (1) CFIUS exceeded its statutory authority in dealing with Ralls' property interests, (2) CFIUS violated the Administrative Procedures Act in exercising its authority, and (3) CFIUS and President Obama acted in an ultra vires manner. See Ralls II, 758 F.3d at 319 . 


\section{Investing near the National Security Black Hole}

As the first legal challenge by a foreign investor to the CFIUS regime, the Ralls case is significant in multiple respects. It elucidates how CFIUS and the President exercised the broad power and discretion granted by the DPA, as amended by FINSA. Ralls shed light, however dim, into the legal black hole of national security review of foreign acquisitions of U.S. businesses. As alluded to earlier, before the enactment of FINSA most of the foreign investments originated from countries considered to be U.S. allies, so CFIUS was not highly active in investigating or blocking the covered transactions. ${ }^{46}$ In response, foreign investors were not incentivized to challenge the agency.

Figure 2: CFIUS Notices Filed and Investigation/Notice Ratio (2005-2014)

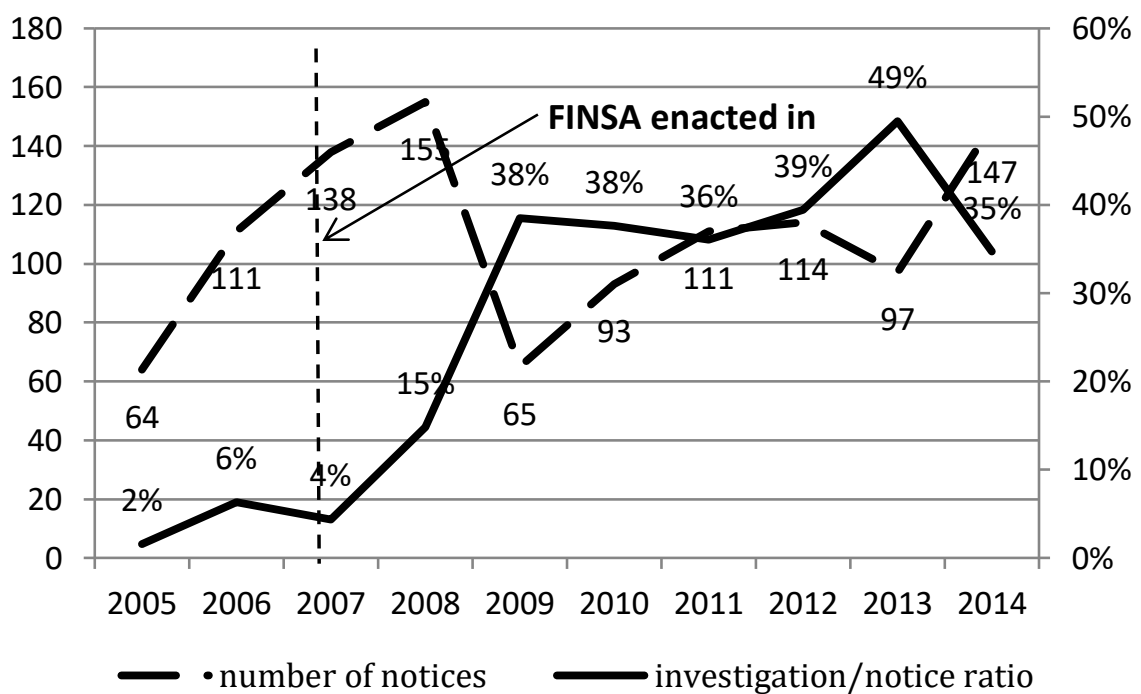

Data source: Annual Reports to Congress (2008-2016) by Committee on Foreign Investment in the United States, available at http://www.treasury.gov/resourcecenter/international/foreign-investment/Pages/cfius-reports.aspx.

Two subsequent changes broke that equilibrium. On the one hand, FINSA mandates heightened scrutiny of covered transactions in certain circumstances. In compliance with the statutory requirement, CFIUS did conduct many more investigations of covered transactions (see Figure 2). On the other hand, investments originating from China soared. Among all the major economies sharing a close trade and investment tie with the United States, China is the only non-ally. ${ }^{47}$ These two changes led to more active CFIUS review and investigation. It is inevitable that, as the tensions grow, external shocks will

46. Zaring, supra note 6 , at 87 .

47. GRAHAM \& MARCHICK, supra note 3, at 103. 
gradually shift the original equilibrium to a new one. The D.C. Circuit decision in Ralls is likely the first of such shocks. It is, therefore, important that scholars analyze the post-Ralls CFIUS system and provide guidance to policymakers, government agents, and foreign investors about the likely future of the regime.

As will be elaborated in the following section, the existing literature on CFIUS has concentrated on the agency. Due to the lack of information about the covered transactions and the agency's decision making process, the literature is mainly comprised of anecdotal case analysis. As will be elaborated in Section III, except for several recent empirical studies, scholarly research in this area is best described as educated guess based on the published annual CFIUS data and high-profile investments rejected by the agency. It is unclear how foreign investors, especially those prone to CFIUS investigations, actually react. The Ralls case demonstrates that foreign investors have played and will continue to play a crucial role in shaping the regime.

To summarize, the CFIUS regime evolved over time in response to recurring political concerns with the negative impacts of foreign investment in the United States. Prior to FINSA, most foreign investments in the United States originated from U.S. allies, so CFIUS did not actively investigate or block covered transactions. Absent active interference from the agency, foreign investors tolerated the uncertainties and arbitrariness of the process and never sued. FINSA altered the equilibrium by requiring heightened agency scrutiny of certain covered transactions. The legislative change coincided with souring investment from China and other countries that are not allies of the United States. Tensions have since been growing between a more active CFIUS exercising broad power and discretion in a non-transparent way and foreign investors lured by the U.S. market and the government's open policy to acquire substantial U.S. assets in diverse sectors. The tensions culminated in Ralls $v$. CFIUS. The case allows the public to peak into the legal black hole of the CFIUS review process and underscores the importance of understanding how foreign investors view and cope with the institution. Yet, as elaborated in the following section, the existing literature offers few clues about the foreign investors' side of the story.

\section{LITERATURE REVIEW}

Public attention on foreign investment in the United States and its national security implications ebbs and flows, and the regulations change accordingly. ${ }^{48}$ The most recent wave ended with the enactment of FINSA. As noted in the preceding section, the institutionalization of national security review of FDI, plus soaring investments from non-ally countries, have given rise to two growing tensions, one between foreign investors and the powerful agency and the other

48. See, e.g., C. S. Eliot Kang, U.S. Politics and Greater Regulation of Inward Foreign Direct Investment, 51 INT'L ORG. 301 (1997). 


\section{Investing near the National Security Black Hole}

between the longstanding policy of keeping an open market and safeguarding U.S. national security. Given their policy and theoretical implications, these tensions have caught much academic attention.

Over time, a sizable literature has accumulated that explores various aspects of CFIUS. As in other controversial areas, scholars generally disagree on the performance, neutrality, and policy desirability of the system. For some, CFIUS represents an institutional innovation that may guide future administrative reform. ${ }^{49}$ The multi-agency structure is able to pool diverse administrative knowledge, block political pressure, and reach rational and consistent decisions. ${ }^{50}$ Others, however, are not so sanguine about the efficacy of the agency and its independence from political influence. ${ }^{51}$ In their view, the breadth of CFIUS's membership and the diversity of institutional interests represented by the member agencies is a principle source of uncertainties that foreign investors have to face in coping with the system. ${ }^{52}$ Vague terms and broad discretions also subject the agency to political influence. One scholar goes as far as labelling CFIUS as "essentially a congressional notification service." 53 Because of the congressional encroachment in the area traditionally and constitutionally reserved for the executive branch, Committee staff would sometimes "advise foreign acquirers to consult with Congress before embarking on mergers." 54

Critical to the debate is a detailed understanding of CFIUS's internal operation, which, due to its national security nature, is severely lacking. Congress intended the agency to operate at a high level of secrecy. Thus, until after Ralls v. CFIUS, "almost nothing [was] known about the internal functioning of the Committee. CFIUS does not disclose its deliberations, nor does it explain its decisions." ${ }^{55}$ For the same reason, "the Committee's legal mandate is replete with discretion." 56 Researchers have had to deduce from observable cases and data which factors affect the decision-making in CFIUS. Some find the Committee review rather spotty, technical, and tightly bound by the law. They point to the fact that out of the hundreds of filings, CFIUS only officially blocked a few of them. For transactions approved with risk mitigation agreements, the Committee mainly focused on whether the foreign investors were government

\footnotetext{
49. Jon D. Michaels, The (Willingly) Fettered Executive: Presidential Spinoffs in National Security Domains and Beyond, 97 VA. L. REV. 878, 880 (2011).

50. Id. at 878 . For a more thorough discussion of the pros and cons of agency structure designed to pool resources, see Daphna Renan, Pooling Powers, 115 COLUM. L. REV. 211 (2015).

51. E.g., Wu \& Frøystadvåg, supra note 29; Zive, supra note 26; Matthew C. Sullivan, CFIUS and Congress Reconsidered: Fire Alarms, Police Patrols, and a New Oversight Regime, 17 WILLAMETTE J. INT’L L. \& DISP. RESOL. 199, 200-01 (2009).

52. Pasco, supra note 1, at 355 .

53. Zaring, supra note 6, at 83 .

54. Id. at 99.

55. Id. at 83 .

56. Id. at 84 .
} 
owned and whether they resided in prosperous allied states. ${ }^{57}$ In other words, CFIUS conducts apolitical review using standards narrowly tailored to U.S. national security risk. On the contrary, others find politics play a major role in CFIUS actions. ${ }^{58}$

As to the policy impacts of the CFIUS regime, the existing research has produced no more than tentative and circumstantial evidence. Recent empirical studies highlight some unintended effects of the CFIUS review such as wealth transfer. ${ }^{59}$ Due to uncertainties created by the review process, foreign investors have to pay more to U.S. sellers than domestic bidders. ${ }^{60}$ Such forced transfer of additional wealth from foreign investors to U.S. shareholders deviates from the alleged legislative intent of the CFIUS system, which is to balance the national security interest and the longstanding policy to "support open investment and national treatment for foreign direct investment." ${ }^{\prime}$ Another type of unintended effect the CFIUS process is enriching a constituency of lawyers and lobbyists who either worked for the agency before or have connections with the members or staff of the agency. ${ }^{62}$

Regarding the general effect of CFIUS on FDI in the United States, some infer from the small numbers of CFIUS filings, investigations, and rejections that CFIUS does not hinder foreign investment. ${ }^{63}$ In contrast, others speculate substantial impact on foreign investment as foreign investors strategically adapt to CFIUS intervention either by refraining from investing in sensitive U.S. business, which is unobservable using typical archival research methods, or by amending their investments to mitigate the risk.

As noted in the preceding section, the judiciary has recently stepped into the fray by mandating the implementation of basic procedures in the CFIUS review process to safeguard the constitutional rights of investigated parties. This further complicated the debate because while some view this as another welcome step to close the legal black hole in the executive branch's exercise of national security powers, ${ }^{64}$ others consider the judicial scrutiny inconsequential to the review process as CFIUS continues to enjoy broad power and discretion. ${ }^{65}$

\footnotetext{
57. Id. at 89 .

58. Tingley, supra note 5, at 27.

59. Paul Connell \& Tian Huang, An Empirical Analysis of CFIUS: Examining Foreign Investment Regulation in the United States, 39 YALE J. OF INT'L L. 131, 163 (2014).

60. Id. at 146-47.

61. Pasco, supra note 1 , at 350-52.

62. Bartz \& Roumeliotis, supra note 25; THEODORE H. MORAN, CHINESE INVESTMENT AND CFIUS: TIME FOR AN UPDATED (AND REVISED) PERSPECTIVE 7 (Sept. 2015), http://www.iie.com/publications/pb/pb15-17.pdf.

63. Zaring, supra note 6, at 103.

64. Andrew Kent, Disappearing Legal Black Holes and Converging Domains: Changing Individual Rights Protection in National Security and Foreign Affairs, 115 CoLUM. L. REV. 1029 (2015).

65. Ji Li, I Came, I Saw, I . . Adapted an Empirical Study of Chinese Business Expansion in the U.S. and its Legal and Policy Implications, 36 NW. J. INT'L L. AND BUS. 143 (2016).
} 


\section{Investing near the National Security Black Hole}

Though more have joined the intricate and heated debate about CFIUS and its policy implications, the gaps in the literature remain wide open. In particular, apart from anecdotal reports about foreign investors' complaints of CFIUS's lack of transparency and certainty, there have not been any systematic studies about how foreign investors actually view and react to the CFIUS mechanism. This article narrows the gap by empirically examining the ways in which Chinese companies investing in the United States perceive and cope with CFIUS. I select Chinese companies as they occupy the central stage of the ongoing debate. China has surpassed Canada to be the largest trading partner of the United States. ${ }^{66}$ Meanwhile, the United States has just become the largest national recipient of China's outbound direct investment. The economic integration, however, can barely disguise the political distrust between the two governments. Chinese investments into the United States pose the most acute problem for CFIUS. As noted earlier, since 2012, Chinese investors have filed the most CFIUS notices each year, surpassing both the U.K. and Japan. Additionally, the only three transactions blocked by the President in the entire history of CFIUS were all by Chinese investors. ${ }^{67}$ In short, analyzing how Chinese companies view and react to the CFIUS regime is crucial to understanding how the institution actually impacts foreign investment in the United States and how it may safeguard U.S. national security.

\section{To FILE OR Not to FILE? - The Foreign INVESTOR's DeCISION TREE}

As discussed in the preceding section, Exon-Florio authorizes the President to block a covered transaction that threatens to impair U.S. national security. This power is not time-barred. So, essentially, all foreign investments in U.S. business are contingent on the risk of a Presidential veto. ${ }^{68}$ To manage and mitigate this risk, foreign investors may get an approval from CFIUS, which bars the agency's future review and investigation. In other words, foreign investors may seek CFIUS review prior to a covered transaction, which, if approved, will be protected from the President's future exercise of a veto to block the

66. Victoria Stilwell, Cheap Oil Helps China Unseat Canada as Top U.S. Trade Partner, BLOOMBERG (Nov. 4, 2015), http://www.bloomberg.com/news/articles/2015-11-04/cheap-oil-helpschina-unseat-canada-as-top-u-s-trade-partner.

67. On December 2, 2016, President Obama blocked the purchase by a Chinese investor of Aixtron, a German semiconductor company with substantial U.S. operations. Paul Mozur, Obama Moves to Block Chinese Acquisition of a German Chip Maker, N.Y. TIMES (Dec. 2, 2016), https://www.nytimes.com/2016/12/02/business/dealbook/china-aixtron-obama-cfius.html?_r=0.

68. Though the D.C. Circuit decision proffered due process protection on foreign investors' property interests in U.S. businesses, it does not at all diminish the President's power to find national security risk of the covered transaction and order divestiture. 
investment. ${ }^{69}$ So, at its core approval by CFIUS offers a safe harbor protection to a covered transaction. ${ }^{70}$

When do foreign investors seek this protection? Prior research is largely silent about this question. To fill the gap, this study focuses on Chinese investors' perception of, and reaction to, the CFIUS system. Before analyzing the empirical data, I elaborate on the complex decision that a rational foreign investment has to make regarding the filing of a notice with CFIUS. The stylized decision tree below illustrates the major components and steps of a foreign investor's calculus. As will be pointed out, some nuances of the process are omitted for the sake of simplicity. Additionally, I assume that investing in the United States produces positive return in order to concentrate on the question of whether the foreign investor is better off filing a notice prior to the investment or proceeding with the investment without notifying CFIUS.

Figure 3: Calculation of Foreign Investor re CFIUS Filing*

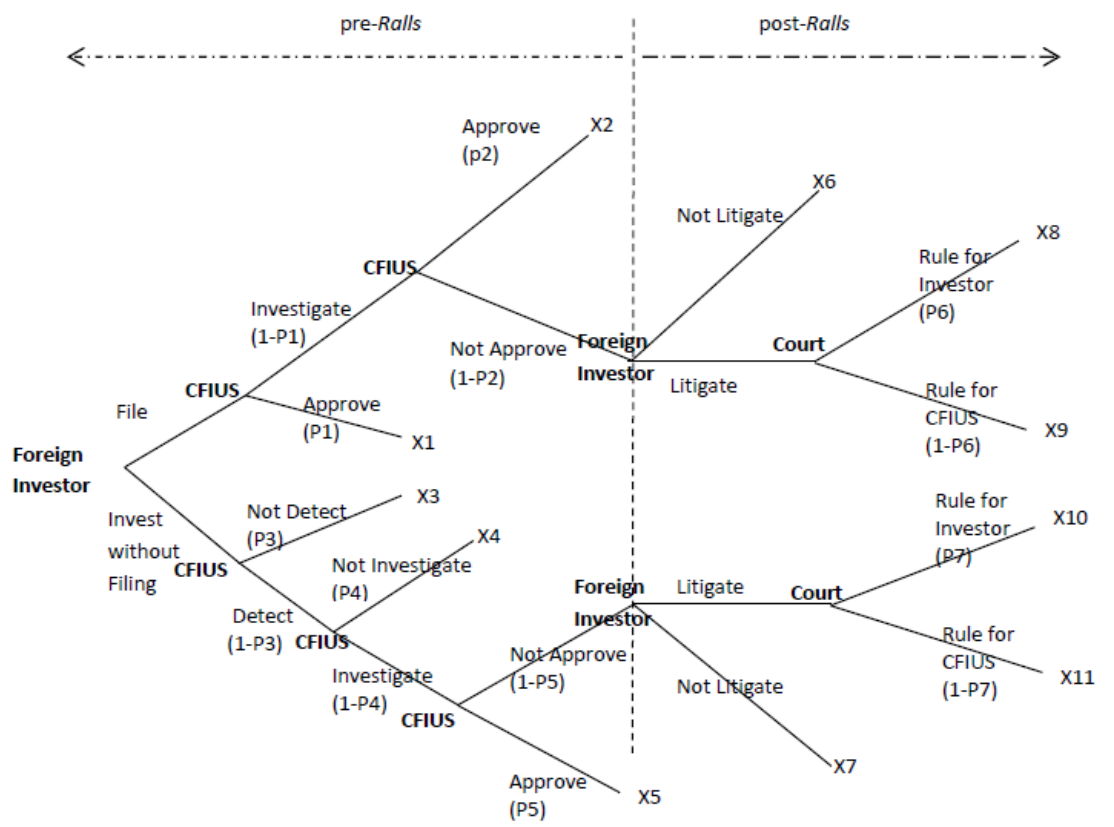

*This decision tree provides a simplified description of the payoff calculation for foreign investors considering whether to make a CFIUS filing. Note that a few important steps in CFIUS process are omitted, e.g., CFIUS may impose risk mitigation measures on the foreign investor and foreign investors often enter into prefiling interactions with CFIUS to assess the necessity of a filing.

69. 50 U.S.C. app. $\S 2170(\mathrm{~b})(1)(\mathrm{D})$ (2006).

70. Pasco, supra note 1, at 354. 


\section{Investing near the National Security Black Hole}

\section{A. Pre-Ralls Calculation}

The decision tree lays out the major actions each of the actors potentially involved in a CFIUS process may take and their respective payoffs. Ps stand for the perceived probability of certain event occurring or action taken, and Xs symbolize the net cost or benefit associated with the chains of events and actions. Basically, a foreign investor engaging in a covered transaction compares the expected payoffs from (i) making a CFIUS filing prior to its investment to the expected payoffs from (ii) investing without notifying CFIUS. The filing of notice with CFIUS, a potentially costly and exhaustive process, ${ }^{71}$ entails two decisions by the agency. First, after a review of the filing within 30 days, the agency decides whether or not to initiate an investigation. If the agency deems the acquisition to be an insignificant threat to U.S. national security, it should approve the transaction. Otherwise, or if more study is needed, CFIUS will initiate an investigation. Moreover, under certain conditions such as the possibility of foreign government control of U.S. assets, CFIUS should automatically open an investigation. ${ }^{72}$

The second decision for CFIUS, if it decides to investigate, concerns whether to approve the acquisition or prohibit it. In the stylized decision tree above, two nuances are disregarded. First, CFIUS may, and in fact quite frequently does, negotiate with foreign investors for a mitigation plan to eliminate any perceived national security risk and approve the acquisition upon the plan's implementation. ${ }^{73}$ For the sake of analytical simplicity, this action is treated as approval with lower payoffs for the foreign investor. Second, under current law CFIUS merely assists the President in making the final decision regarding the approval or blocking of the foreign acquisition. In this decision tree the two are treated as a unified actor when a final decision regarding a covered transaction is rendered. The President has fully delegated the review to CFIUS, and it is generally expected that he will adopt CFIUS's recommendations.

In the event of a rejection by CFIUS, the investor may consider litigating the decision in a U.S. court. Prior to the D.C. Circuit decision in Ralls II, the expected payoff from a favorable judgment was minimal. Given the national security and foreign affairs natures of the matter, it was reasonable to expect U.S. judges to take a highly deferential position as seen in the trial court for the Ralls case. With a close-to-zero probability of prevailing in court, the foreign investor was unlikely to litigate an unfavorable CFIUS determination. As discussed earlier, not a single foreign investor filed a lawsuit in a U.S. court against CFIUS for decades.

71. Connell \& Huang, supra note 59, at 133.

72. 31 C.F.R. $\S 800.503$ (b)(1) (2011), unless the Chairperson of the Committee and the head of any lead agency designated by the Chairperson determine that the covered transaction will not impair U.S. national security. 31 C.F.R. $\S 800.503$ (c).

73. 31 C.F.R. $\S 800.101$ (2015). 
On the other hand, if the foreign investor did not file a notice with CFIUS prior to its investment, it faced a different set of expected payoffs. First of all, it is important to note that CFIUS may not have detected the investment. Each year foreign investors make hundreds of mergers and acquisitions that target U.S. businesses. Because CFIUS is an agency of limited administrative capacity, it is not possible or even desirable to keep track of all of these transactions, let alone review most of them. As a former staff member observed, "CFIUS reviewed a mere 88 transactions in 2010 and would genuinely have preferred not to review even that many." 74 Without CFIUS having any knowledge about a covered transaction, the investor faces no risk of investigation or any mitigation measures. So, the foreign investor first calculates the expected probability of CFIUS finding out about its investment which should hinge on a myriad of factors including the investor's identity, the size and profile of its investment, the sensitivity of the investment, media attention, and its efforts to conceal the transaction.

Since CFIUS investigation is not time-barred, the President may impose onerous risk mitigation measures or even reverse a covered transaction years after its consummation. ${ }^{75}$ The infinite time horizon should factor into the calculation of the expected payoff because the longer a foreign investor plans to operate acquired U.S. assets, the more likely CFIUS will discover the transaction. For instance, assuming the probability of detecting or paying attention to a certain unreported transaction is only 5\% annually, the probability that CFIUS will neglect the transaction drops to $40.1 \%$ if the foreign investor operates the assets for ten years, $7.7 \%$ for fifty years, and $0.6 \%$ for one hundred years.

In the event a foreign investor decides to proceed with an acquisition of U.S. assets without filing a voluntary notice and CFIUS subsequently becomes aware of the covered transaction, the agency will decide, after a brief review, whether to investigate the transaction. ${ }^{76}$ Absent certain conditions such as foreign government control, CFIUS may opt to ignore it. Otherwise, or if it considers the transaction to pose a possible national security threat, the agency may initiate an investigation. The investigation may result in a de facto approval, i.e., not taking any retrospective action against the consummated transaction. The agency may alternatively find that the investment constitutes a national security threat and impose onerous mitigation measures, including an ordered divestiture.

\footnotetext{
74. Pasco, supra note 1 , at 356.

75. $I d$.

76. The Regulations provide that the Staff Chairperson of CFIUS first request the parties to the transaction to submit information to make the determination of whether the transaction is a covered transaction. If so, it may then request the parties to file a notice. See C.F.R. $\S 800.401$ (c). In addition, any member of CFIUS may file an agency notice to the Committee through the Staff Chairperson regarding a transaction for which no voluntary notice has been filed. But such a filing must be made within three years after the completion of the transaction. See 31 C.F.R. $\S 800.401$ (b) (2011).
} 


\section{Investing near the National Security Black Hole}

In such a case, the foreign investor bears all the costs of divesting in an imposed short time frame and on a highly restricted market, as exemplified by Ralls.

Before the D.C. Circuit decision in Ralls, this would likely have been the end of the foreign investor's calculation, as the expected payoffs from litigating a negative agency decision were minimal given the judicial deference in cases touching on national security and foreign affairs and the clear statutory language to shield the actions and the findings of the President from judicial review. ${ }^{77}$ As noted earlier, the highly confidential administrative process without effective judicial scrutiny was properly analogized to a legal black hole. ${ }^{78}$ Rational foreign investors compare the expected payoffs from making the filing prior to investment with those from investing without notifying CFIUS and takes the approach that maximizes its expected return. For instance, a high profile covered transaction by a well-known foreign corporation that is fully owned by a hostile foreign government will likely trigger CFIUS investigation, so it is generally in the foreign investor's interest to file the notice in order to obtain the safe harbor protection. By contrast, a covered transaction by an obscure private foreign investor from a U.S. ally of a small U.S. business is unlikely to catch the attention of CFIUS, and even if it does, the investor reasonably expects the agency's nonfeasance or approval. Thus, a foreign investor is likely to skip the filing before investment because the cost of obtaining the safe harbor protection likely exceeds the benefit. ${ }^{79}$ To be more specific, a foreign investor will file a CFIUS notice prior to investment if and only if the expected payoff from filing exceeds the expected payoff from skipping the filing, or in other words, the payoff from (1) is larger than the payoff from (2) below.

Expected payoff from filing a CFIUS notice prior to investment:

$P 1 * X 1+(1-P 1) *[P 2 * X 2+(1-p 2) * A]$, where $A=\operatorname{Max}\{X 6,[P 6 * X 8+(1-P 6) * X 9]\}$

$(1)$

and the expected payoff from investing in the United States without notifying CFIUS is:

$P 3 * X 3+(1-P 3) *[P 4 * X 4+(1-P 4) * C]$, where $C=(1-P 5) * B+P 5 * X 5 \quad \& \quad B=\operatorname{Max}\{X 7$, $[P 7 * X 10+(1-P 7) * X 11]\}$

(2).

77. 50 U.S.C. app. $\$ 2170(\mathrm{~g})(2006)$.

78. Kent, supra note 64, at 1083 (discussing the Ralls case as an example that the courts are closing the legal black holes).

79. Legal fees for CFIUS review typically range from $\$ 50,000$ to $\$ 2$ million. 


\section{B. The D.C. Circuit Decision in Ralls Has Changed the Calculation}

Ralls is no doubt a watershed case. As described earlier, the case pertains to a foreign investor failing to file a notice with CFIUS prior to a covered transaction. The trial court decision virtually maintained the expected payoffs in the decision tree as described in Subsection A. The trial judge put herself in the shoes of the foreign investor. From such an angle, the judge considered the investor's decision to not file a CFIUS notice as a willing assumption of the risk of a Presidential veto. ${ }^{80}$ Under the pre-Ralls rules, all covered transactions without CFIUS approval resulted in the foreign investors holding U.S. assets contingent on the President not exercising the blocking power. In other words, foreign investors who opt not to obtain the safe harbor of CFIUS approval merely acquire "contingent" property rights in the U.S. assets subject to veto. ${ }^{81}$

The D.C. Circuit disagreed and proffered the constitutional due process protection over foreign investors' U.S. assets acquired through a covered transaction. The court ordered CFIUS to provide the foreign investor with unclassified evidence and an opportunity to rebut. ${ }^{82}$ The constitutional protection extended to foreign investors should have altered the expected payoffs of the decision to not file a notice with CFIUS before investment. After Ralls, if a foreign investor fails to make a filing with CFIUS prior to a covered transaction, and CFIUS subsequently initiates an investigation and decides to sanction the foreign investor, the agency will have to follow more onerous procedural requirements. In theory, that should increase the expected payoff for the investor from skipping the filing. More importantly, the Ralls decision altered foreign investors' expectations about judicial scrutiny of CFIUS actions, i.e., a higher probability of active judicial review. Of course, it is costly to litigate in the United States against a federal agency, so the foreign investor will take that approach only if substantial interest is at stake.

In theory, the Ralls case further separated the expected payoffs from the two diverging initial decisions, i.e., to file or not to file prior to embarking on a covered transaction. By choosing to file, the foreign investor postpones the acquisition of property interests in any U.S. assets. So the judicial review, which is more conceivable after Ralls, does not concern protected interests for constitutional due process purposes. ${ }^{83}$ The courts will be highly deferential towards the agency, so the foreign investor reasonably expects negative payoffs from litigating an unfavorable CFIUS decision. In other words, the D.C. Circuit decision does not alter the pre-Ralls world if the foreign investor chooses to file a notice with CFIUS prior to a covered transaction. As some practitioners

80. Ralls Corp. v. Comm. On Foreign Inv. in U.S. (Ralls I), 987 F. Supp. 2d 18, 27 (D.D.C. 2013), rev'd and remanded, 758 F.3d 296 (D.C. Cir. 2014).

81. Id.

82. Ralls Corp. v. Comm. On Foreign Inv. in the U.S. (Ralls II), 758 F.3d 296, 325 (D.C. Cir. 2014).

83. Ralls I, 987 F. Supp. $2 \mathrm{~d}$ at $27-29$. 


\section{Investing near the National Security Black Hole}

observed, "since the D.C. Circuit's opinion, CFIUS has shown no inclination to offer foreign investors rights to rebut evidence in standard CFIUS cases, nor even in cases in which the relations between CFIUS and the parties become acrimonious." $\$ 4$

In contrast, if the foreign investor invests without first filing a notice with CFIUS, it acquires property interests in the U.S. assets. Such property interest, under Ralls, entitles the foreign investor to constitutional due process protection. Thus, CFIUS's administrative actions will be subject to more intrusive judicial scrutiny. Everything else being equal, Ralls transformed the payoffs for foreign investors in such a way that they have more incentives to skip CFIUS filing before investing in U.S. assets.

Of course, everything else may not be equal. Evidently, if CFIUS intends to maintain the same payoffs from filing a notice, all it would have to do is change the probability of detection or the probability of investigation. In order to do so, however, CFIUS would have to boost its administrative capacity. The agency would need to collect more information about foreign acquisitions of U.S. assets that may potentially pose national security threats and would need more resources to investigate the transactions. Moreover, the agency could achieve the same objective by significantly altering the probability of approving a covered transaction in the event the foreign investor failed to file a notice prior to a covered transaction.

Alternatively, the agency could adjust the payoffs for filing the notice in order to achieve the same outcome as in the pre-Ralls regime. It could do so by raising the expected return from filing the notice, e.g., making it easier to obtain approval for the foreign investor that files a notice with CFIUS. Though the D.C. Circuit decision does not substantively implicate agency actions following the "filing prior to investment" branch of the decision tree, and CFIUS has not yet showed any sign of altering its procedures, the agency could nonetheless feel some pressure in the future to reform its procedures in order to narrow the payoff gap between the "to file" decision and the "not to file" decision.

In short, Ralls triggered chain effects on the calculation of foreign investors engaging in covered transactions. A new equilibrium of the interactions between CFIUS and foreign investors will emerge in due time. Its final form, however, will also be affected by several contextual factors. As noted, the probability of CFIUS attention and investigation is a variable of not only agency administrative capacity, but also the relations between the U.S. government and the home country of the foreign investors. ${ }^{85}$ Investors from a country that is a close ally of the United States (e.g., Korea or Japan) will certainly be treated differently

84. Stewart Baker \& Stephen Heifetz, Ralls May Give Foreign Investors More Leverage with CFIUS, LAW360 (Dec. 11, 2014), https://www.law360.com/articles/603312/ralls-may-give-foreigninvestors-more-leverage-with-cfius.

85. Jiang \& Li, supra note 14, at 95-96. 
from those of non-allies (e.g., China or Russia) for the analysis of national security threat. ${ }^{86}$

To summarize, this section illustrates the calculations of rational foreign investors involved in covered transactions both before and after the Ralls case and how the D.C. Circuit decision has altered the expected payoffs of the decisions. The changes, however, are conditioned on holding other variables constant. For instance, CFIUS can increase its administrative capacity to maintain the current level of filing incentives without lowering the standards of investigation or approval. In addition, the model is stylized to highlight some of the major actions of the parties to a CFIUS process. ${ }^{87}$ The next section will empirically examine how Chinese investors in the United States actually view and cope with the CFIUS system, and the impact, if any, of Ralls.

\section{CHINESE INVESTMENTS UNDER THE CFIUS REGIME}

This Section IV presents the first ever empirical analysis of Chinese investments under the CFIUS framework. It is divided into four parts. First, I briefly describe the growth of Chinese investment in the United States. Second, I discuss the surveys conducted in 2014 and 2015 from which data for this study is derived. Third, I provide an empirical overview of several major topics concerning Chinese investments and CFIUS. Fourth and last, I conduct statistical analysis of three issues central to the ongoing debate.

\section{A. Chinese Investments in the United States}

After four decades of continuous growth, China has transformed from an isolated and autarkic country into an open economy second in size only to the United States. Meanwhile, China has turned from a capital-importing state to one of the largest sources of global outbound investment. While many early Chinese investments flew to resource-rich developing countries, in the past decade an increasing number of China-based multinationals ventured into more mature and competitive markets. Chinese investment in the United States has largely followed this trajectory (see Figure 4). ${ }^{88}$ By one estimate, Chinese invested $\$ 45.6$ billion in the United States in 2016, a $200 \%$ increase from the amount in $2015 .{ }^{89}$

\footnotetext{
86. Id. at 96 .

87. Omitted from the model, for instance, is the uncertainty in the process and the investors' decision-making under uncertainty.

88. Economist Intelligence Unit, China Going Global Investment Index (2013), http://china.ucsd.edu/_files/odi-2013/09232013_Paper_Liu_ChinaGoingGlobal.pdf.

89. Thilo Hanemann \& Cassie Gao, Record Deal Making in 2016 Pushes Cumulative Chinese FDI in the U.S. above $\$ 100$ billion (Dec. 30, 2016), http://rhg.com/notes/record-deal-making-in-2016-pushescumulative-chinese-fdi-in-the-us-above-100-billion.
} 


\section{Investing near the National Security Black Hole}

Figure 4: Chinese FDI in the United States (historical-cost basis, 20022014; in million U.S. dollars)

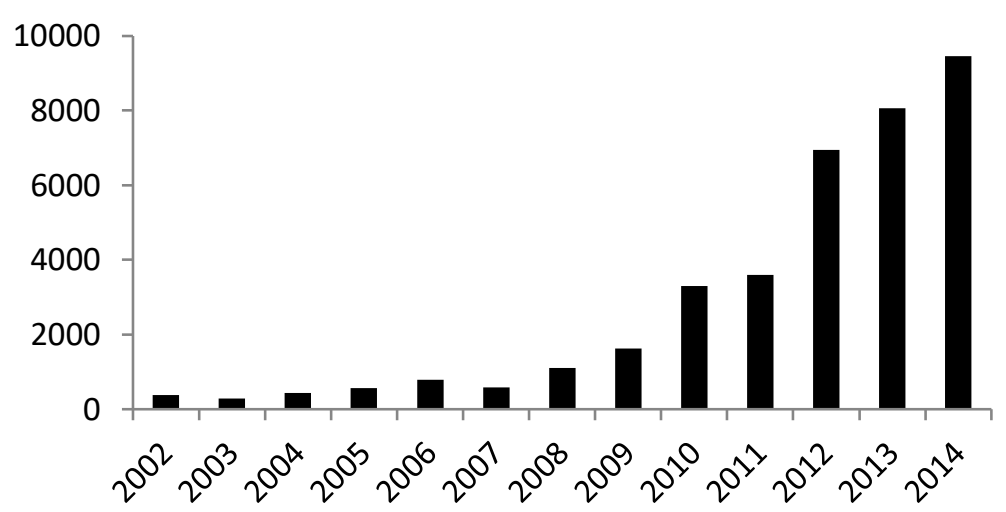

Data source: Bureau of Economic Analysis, U.S. Department of Commerce, at http://www.bea.gov/international/dilfdibal.htm.

Due to its scale and potential ramifications, China's outward FDI has spawned a sizable amount of literature on a wide range of topics. ${ }^{90}$ Yet very few have explored how China-based multinationals cope with typically complex regulatory institutions in developed countries. In particular, no prior study has systematically examined the tension between Chinese FDI and national security concerns expressed by host countries. That tension manifests acutely in the United States which, for various reasons, has kept at best lukewarm diplomatic relations with China. This study will fill the gap in the literature and make several theoretical and policy contributions.

\section{B. The Surveys of Chinese Companies in the United States}

Unlike most of the existing research, which is based on anecdotal reports or aggregated data published by CFIUS annually, this study relies on empirical

90. See, e.g., Syed Tariq Anwar, FDI Regimes, Investment Screening Process, and Institutional Frameworks: China Versus Others in Global Business, 46 J. OF WORLD TRADE 213 (2012); Diego Quer, Enrique Claver \& Laura Rienda, Political Risk, Cultural Distance, and Outward Foreign Direct Investment: Empirical Evidence from Large Chinese Firms, 29 ASIA PAC. J. OF MGMT. 1089 (2012); Jun Xia et al., Outward Foreign Direct Investment by Emerging Market Firms: A Resource Dependence Logic, 35 StRategic MgMT. J. 1343 (2014); Andrew Szamosszegi, An Analysis of Chinese Investments in the U.S. Economy, in CHINESE INVESTMENTS IN THE U. S. ECONOMY: SELECT ANALYSES 1 (Zackary A. Michaud ed., 2013); Mike W. Peng, The Global Strategy of Emerging Multinationals from China, 2 Global Strategy J. 97 (2012); Bala Ramasamy, Matthew Yeung \& Sylvie Laforet, China's Outward Foreign Direct Investment: Location Choice and Firm Ownership, 47 J. OF WORLD BUS. 17 (2012); Chengqi Wang et al., What Drives Outward FDI of Chinese Firms? Testing the Explanatory Power of Three Theoretical Frameworks, 21 InT'L BuS. REv. 425 (2012); Ivar Kolstad \& Arne Wiig, What Determines Chinese Outward FDI?, 47 J. OF WORLD BUS. 26 (2012); and THEODORE MORAN \& LINDSAY OLDENSKI, FOREIGN DiRECT INVESTMENT IN THE UNITED STATES: BENEFITS, SUSPICIONS, AND RISKS WITH SPECIAL ATTENTION TO FDI FROM CHINA (2013). 
evidence derived from two annual surveys of large Chinese companies operating in the United States. The surveys were conducted by the Chinese General Chamber of Commerce-U.S.A. ("CGCC"), the dominant Chinese business association in the United States. ${ }^{91}$ Founded in 2005, the CGCC now has six regional chapters that cover all 50 states. General members of the CGCC comprise of selected Chinese companies investing in diverse sectors and locations in the United States. The surveys, written in simplified Chinese, cover a wide array of topics ranging from investors' business performance to their compliance with several major U.S. laws and regulations.

In summer 2014, the CGCC staff distributed the survey questionnaires in two ways. First, the survey was circulated to all CGCC members. Most of the members of the CGCC board and the regional chapters completed the questionnaires, which ensured a diverse sample of the U.S. affiliates of large China-based multinationals. Second, a senior staff member of the CGCC interviewed about a dozen executives of Chinese companies in the United States, many of whom timely returned a completed questionnaire. ${ }^{92}$ In all, the CGCC collected 101 completed questionnaires over two months, with a total response rate of approximately $33 \%$. In summer 2015 , the CGCC staff repeated this process, but relied solely on the survey questionnaires and collected 122 responses, many of which were completed by members of the CGCC board and the boards of its local chapters.

Because of the high response rate from board members, the survey sample is diverse in multiple aspects. Under its organizational policy, the CGCC elects sizable Chinese companies representing different sectors, locations, corporate structure and ownership to lead the board and its regional chapters. ${ }^{93}$ As a result, the survey respondents are highly diverse in terms of sectors, duration of investment in the United States, ownership structure, and investment location. ${ }^{94}$

The primary benefits of the surveys' methodology are direct insights about managerial perceptions, considerations and motives that are unobservable using archival data. Yet the method also has its drawbacks. Problems of bias common to all survey-based research will be addressed when the findings are presented below. Limited sample size is also a legitimate concern. As Chinese companies only recently began to invest in developed countries, the pool of sizable Chinese

91. The author participated in the survey project as a non-paid academic advisor, and provided comments on its administration and the analysis of the survey results.

92. An Association staff member other than the interviewing director compiled the survey results to avoid possible feedback bias.

93. See China General Chamber of Commerce-U.S.A., http://www.cgccusa.org/about/governance/ (last visited Jan. 10, 2016).

94. In line with findings from other studies of Chinese investment in the United States, California stands out as the most popular destination, which is trailed by New York and New Jersey. States in the Midwest and the South are also represented in the sample. Cf., Rhodium Group, New Neighbors: Chinese Investment in the United States by Congressional District: Executive Summary (May 2015), http://rhg.com/wp-content/uploads/2015/05/NewNeighborsExSum.pdf. 


\section{Investing near the National Security Black Hole}

investors in the United States remains relatively small. ${ }^{95}$ Nonetheless, the survey results are informative because the sample includes most of the largest Chinese companies operating in the United States.

\section{Empirical Overview of the Survey Data on Chinese Investors and CFIUS}

\section{Consideration and Filing with CFIUS}

The survey finds the majority of the respondents did not consider the possibility of CFIUS review when making their U.S. investments (see Figure 5). One may explain this surprising finding as rational reactions by Chinese investors to the low risk. As discussed earlier, presumably most FDIs pose little threat to U.S. national security, and notifying CFIUS prior to a covered transaction is voluntary. With a small probability of CFIUS investigation and subsequent sanction, the investors are better off not seeking the safe harbor protection by filing a notice prior to the investment. Moreover, under current law greenfield investments fall outside CFIUS's jurisdiction, so those respondents who entered the U.S. market by building businesses from scratch reasonably believe that they do not face the same legal uncertainties. ${ }^{96}$ In addition, as will be illustrated in a moment, many Chinese investors lack any knowledge about the CFIUS system and its potential relationship to their investments. ${ }^{97}$

Furthermore, from CFIUS's perspective, keeping the number of filings low is probably in its best interest, as the lack of administrative capacity handicaps the agency.

95. China does not rank highly on the list of countries investing in the United States. See, e.g., Org. for Int'l Inv., Foreign Direct Investment in the United States 2014 Report 4 (Oct. 2014), http://www.ofii.org/sites/default/files/FDIUS2014.pdf.

96. Though, as will be discussed later, the definition of greenfield investment for purposes of CFIUS review is not entirely free of ambiguity.

97. The lack of knowledge includes both the "unknown unknown," i.e., totally incognizant of even the existence of the CFIUS regime, and the "known unknown," i.e., heard of CFIUS but acquired no knowledge about the agency and the process. 
Figure 5: Considering and filing with CFIUS when investing in the United States

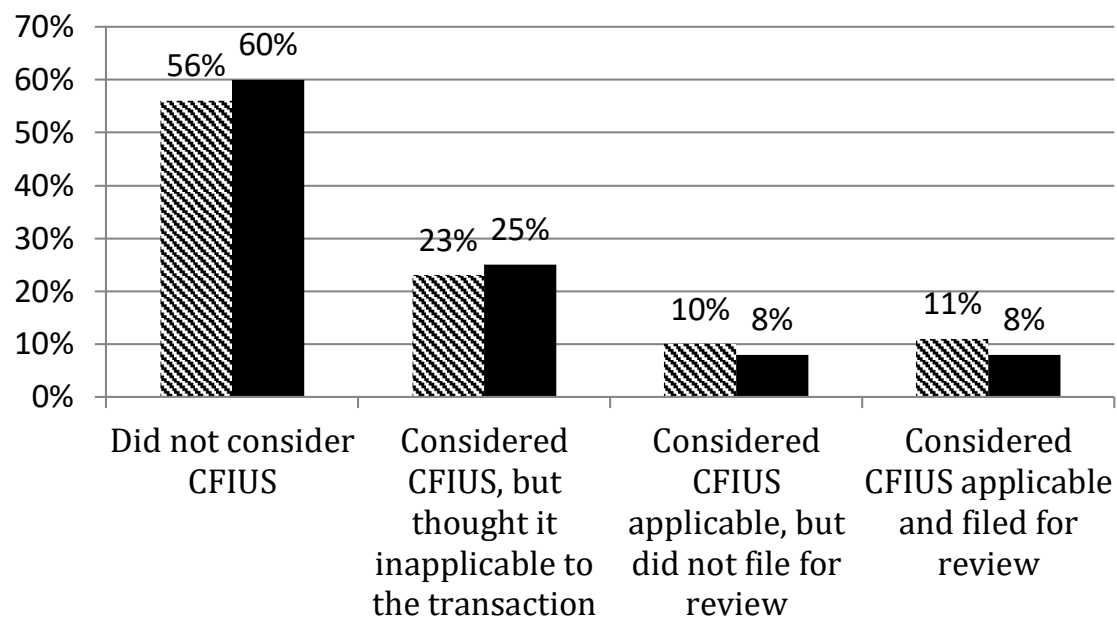

\$ $2014 \square 2015$

Readers should also keep in mind that the sample comprises sizable Chinese multinationals operating in the United States. Because Chinese firms from a random draw would certainly be of smaller size and in fewer sensitive sectors, one should view the percentages (56\% to $60 \%$ of the respondents did not consider CFIUS when investing in the United States) as the lower bound rather than the population mean. In other words, adjusting for possible bias, one can conclude with a high level of confidence that more than $60 \%$ of all Chinese companies investing in the United States have not considered filing with CFIUS.

Among those that had considered CFIUS review when making their investments, the majority concluded that it was inapplicable to their transactions. As noted, CFIUS review applies only to covered transactions. Greenfield investment is exempt. Moreover, some Chinese investors may reasonably conclude that acquisitions of U.S. businesses posing minimal threat to U.S. national security would not incur any risk of CFIUS review.

Among those who had considered CFIUS review to be applicable to their transactions, about half filed a notice with the agency. As discussed in the preceding section, CFIUS filing is voluntary, so foreign investors that do not file the notice violate no law. By intentionally skipping the filing, they simply assume the risk of a subsequent CFIUS investigation and, in case of a finding of national security threat, sanctions such as an ordered divestiture. As illustrated in the decision tree, rational foreign investors would have no incentive to make a CFIUS filing when the expected return from doing so is lower than that from not filing. Suppose a medium-sized Chinese company with $20 \%$ voting interest 


\section{Investing near the National Security Black Hole}

owned by a Chinese provincial government intends to invest in a small U.S. firm manufacturing low-end auto parts. And the investor expects a quick return to the investment. Though under the current law, CFIUS should initiate an investigation if notified, the risk of a finding of national security threat is so low that the Chinese investor is likely better off skipping the filing before making the investment.

\section{Reliance on U.S. Lawyers}

The CFIUS process is complex, opaque and uncertain. Many foreign investors therefore "rely on a relatively small group of experienced lawyers who deal regularly with CFIUS." 98 Do Chinese investors also depend on U.S. lawyers to navigate the system? A prior study suggests that, in general, Chinese investors rely extensively on local professionals to comply with U.S. law. ${ }^{99}$ These surveys find similar results, i.e., U.S. lawyers play an important role in guiding Chinese investors through the CFIUS process. According to the 2014 survey data, 57\% of the respondents consulted U.S. lawyers on matters relating to CFIUS, and eighteen out of nineteen that solicited legal advice adopted it (see Figure 6). ${ }^{100}$ Thus, U.S. lawyers played a central and dominant role in Chinese investors' interactions with CFIUS. Again, because the sample is comprised of sizable Chinese multinationals, and state-owned firms are thus overrepresented, the percentage for legal consultation in a random sample of all Chinese multinationals operating in the United States should be lower than 57\% for 2014 and $79 \%$ in 2015 .

98. Michaels, supra note 49 , at 881 .

99. Li, supra note 65 , at 143 .

100. Because the numbers and compositions of respondents vary slightly for different questions, the percentage of the Chinese companies that consulted U.S. lawyers on CFIUS matters is marginally higher than the percentage that expressed some knowledge about CFIUS review. 
Figure 6: Whether engaged U.S. lawyer in CFIUS review

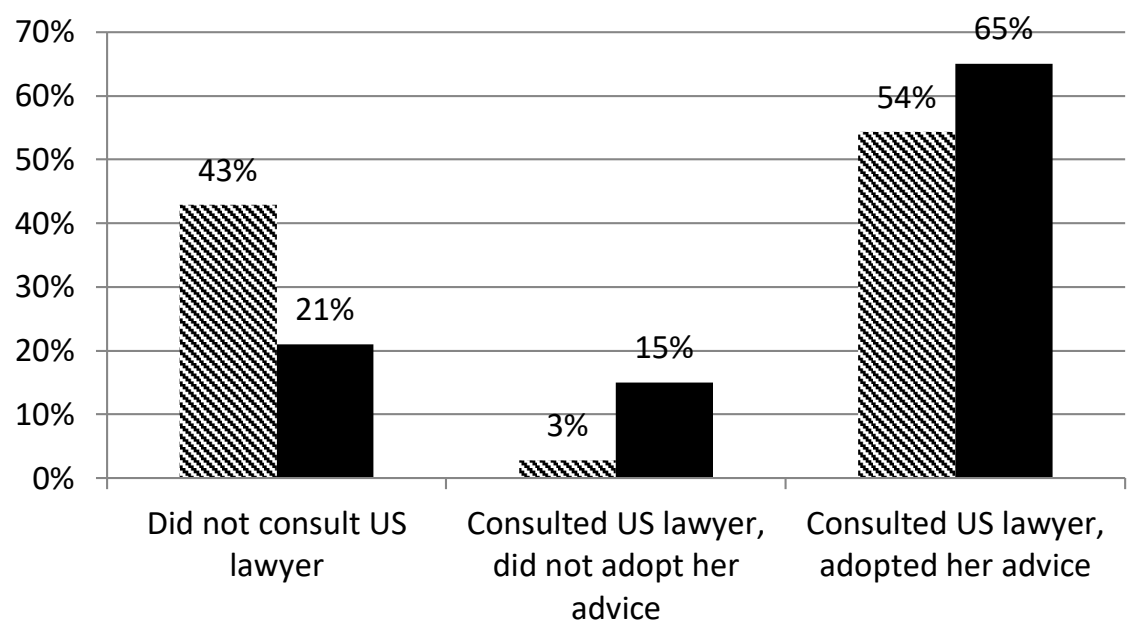

N2014 $\mathbf{\square} 2015$

The 2015 survey data retains the same big picture, but the distribution has changed significantly. Compared to the previous year, more Chinese investors $(80 \%)$ solicited legal advice regarding CFIUS. Conversely, the percentage of investors not consulting any U.S. lawyer about CFIUS dropped by more than half from $43 \%$ to $21 \%$. Meanwhile, the interactions with U.S. lawyers led to different outcomes in 2015. While the percentage of investors who consulted U.S. lawyers and followed their legal advice increased from 54\% in 2014 to $65 \%$ in 2015 , the percentage of investors who dismissed the lawyers' advice surged from $3 \%$ in 2014 to $15 \%$ in 2015 . What explains the shift? I contend that the D.C. Circuit decision in Ralls plays an important role. It is important to note that the case, rather obscure in the United States, made headline news in China. All major newspapers and online media outlets trumpeted the decision as a historic victory for Chinese companies expanding abroad. Because of its publicity, Ralls educated Chinese investors about the importance of law in the CFIUS process, which explains why more companies consulted lawyers on the matter afterwards. ${ }^{101}$

On the other hand, Ralls also vitiated the credibility of the CFIUS "experts." The appellate decision took most of them by surprise. ${ }^{102}$ The outcome probably

101. Ralls II was decided on July 15, 2014. Most of the 2014 survey questionnaires (59/101) were collected before the D.C. Circuit decided Ralls on July 15, 2014.

102. CFIUS experts all opined that the trial court got the law right. See, e.g., Daniel B. Pickard, Nova J. Daly \& Usha Neelakantan, The Ralls Case: Why CFIUS and the Court Got it Right, 8 GLOBAL TRADE \& CuSTOMS J. 192 (2013); and Jeremy Zucker \& Hrishikesh Hari, Gone with the Wind II: The Ralls Decision and Lessons for Foreign Investors, 9 GloBAL TraDE \& CUSTOMS J. 44 (2014). Prior to 


\section{Investing near the National Security Black Hole}

taught Chinese investors to take their lawyers' advice with a grain of salt, hence the much higher percentage of respondents who refused to follow the legal advice of their lawyers. Moreover, it is possible that having learned about CFIUS from reading news reports of the Ralls case, some investors that would have been better off skipping the filing felt it necessary to get a professional opinion. Lawyers, being risk-averse and incentivized by potential legal fees, likely advised for filing a notice in most situations. Their clients, however, run different calculations and some may have decided not to adopt their lawyers' advice. ${ }^{103}$

\section{Perception of CFIUS}

Compliance depends heavily on the perception of the legal process. ${ }^{104}$ Thus, to assess the effect of the CFIUS system, it is important to analyze foreign investors' view on it. As discussed earlier, because of CFIUS's restrained jurisdiction, certain Chinese investors should be "rationally ignorant" about the regime. In other words, Chinese investors exposed to little risk of CFIUS investigation should not invest in acquiring sufficient knowledge about the agency and therefore would not hold any specific view about it. The survey data confirms this hypothesis. As illustrated in Figure 7, slightly less than half of the respondents reported to know little about CFIUS review. Among those that had some knowledge, the majority considered the regime politicized and nontransparent. This finding is not surprising. The agency, before Ralls, was under no obligation to explain its analysis and decisions, or to provide an opportunity to the investors to rebut the evidence against them. Again, the percentages of Chinese firms lacking any knowledge of CFIUS should be viewed as the lower bounds for the percentages from a random sample of all Chinese companies operating in the United States.

\footnotetext{
the initial District Court ruling, CFIUS experts estimated the probability of Ralls prevailing in court to be less than 1\%. Sanyi Su Aobama An Lushi Xia TingKang: Hexin Suqio Huo Shouli [Lawyer Xia TingKang for Ralls v. Obama: Core Claim Accepted], Xinlangcaijing (Mar. 2, 2013), http://finance.sina.com.cn/hy/20130302/100514697913.shtml.

103. Of course, caution should be exercised not to over-interpret the change in percentages from $3 \%$ to $15 \%$, as the corresponding change in absolute numbers is relatively insignificant.

104. TOM R. TyLer, Why PeOPle OBeY the LAW 161-69, 178 (1990).
} 
Figure 7: View regarding the CFIUS process

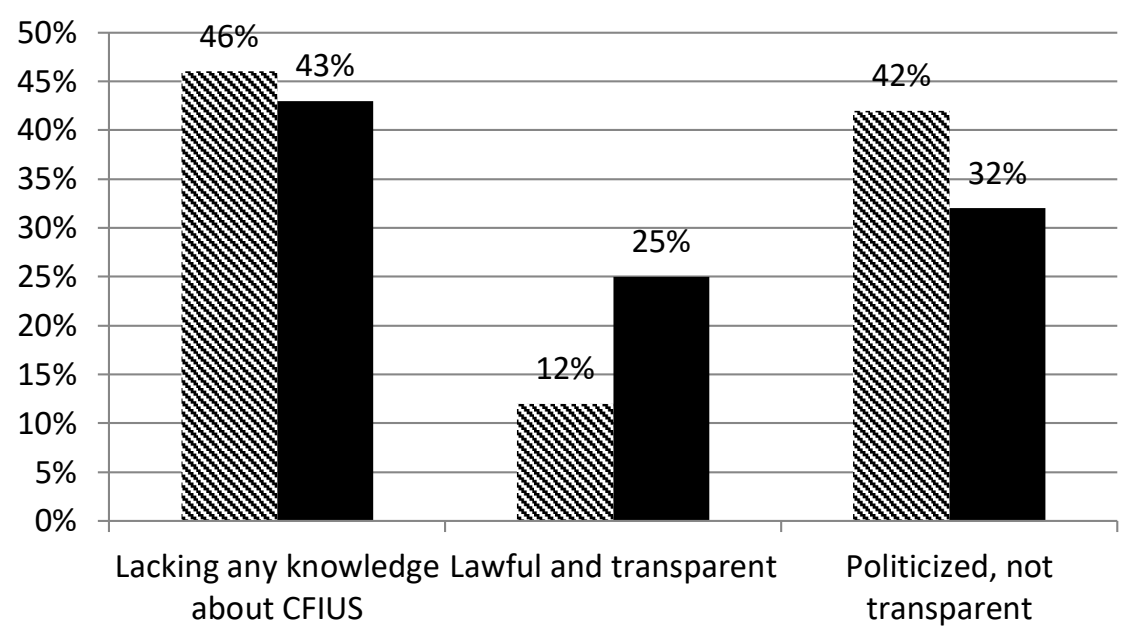

\$ $2014 \square 2015$

But note the dramatic opinion shift in the graph above. From the time of the 2014 survey to that of the 2015 survey, the percentage of Chinese investors considering CFIUS to be lawful and transparent more than doubled. Two factors might have contributed to this drastic change. First, more Chinese investors consulted U.S. lawyers, who are mostly former government agents who worked for CFIUS and were able to provide some guidance to the investors about the review process. ${ }^{105}$ Second, Ralls may have a positive influence as the investor plaintiff eventually prevailed in the D.C. Circuit against CFIUS and the President. As noted earlier, the judgment made headlines in all Chinese newspapers and online news channels within days of its publication. ${ }^{106}$ The outcome might have convinced many Chinese investors that the CFIUS regime is governed by the constitutional framework. Of course, some other variables that changed over the two years might have contributed to the improved perception. I will conduct more rigorous analysis in Subsection D to assess the validity of the hypothesized effect of Ralls.

105. Bartz \& Roumeliotis, supra note 25 .

106. See, e.g., Wu Chengliang, Sanyi Zhonggong Zai Meiguo Daying Guansi [Sanyi Heavy Machinery Won Suit in US], PEOPLE's DAILY, July 17, 2014; Liu Jiao, Sanyi Zhonggong Guanlian Qiye zai Meiguo Gaoying Aobama [Affiliate of Sanyi Heavy Machinery Won Suit Against Obama in US], XINHUA NET, July 16, 2014; SINA, one of the most popular online news portal, operated a special column (titled Sanyi Group Won Lawsuit Against Obama) for the lawsuit: http://finance.sina.com.cn/focus/sanyiabm/. 
Investing near the National Security Black Hole

\section{Deterrence of CFIUS}

As noted earlier, so far most of the debates revolving around CFIUS rely on anecdotal reports and summary statistics published annually by the agency. With these statistics, we have not been able to observe the counterfactual, i.e., how many acquisitions could have occurred but for the investors' concern with CFIUS review. According to the surveys, slightly more than $10 \%$ of those who considered CFIUS review gave up some investments due to concerns with the process. This finding provides solid evidence that the regime has measurable deterrence effect. However, whether the deterrence results in any loss of efficiency is still unknown. It is not ascertained what proposed investments were abandoned due to the concern with CFIUS review and whether they actually pose any serious national security threats.

Figure 8: Have you ever given up an investment in the U.S. due to concern with CFIUS review?

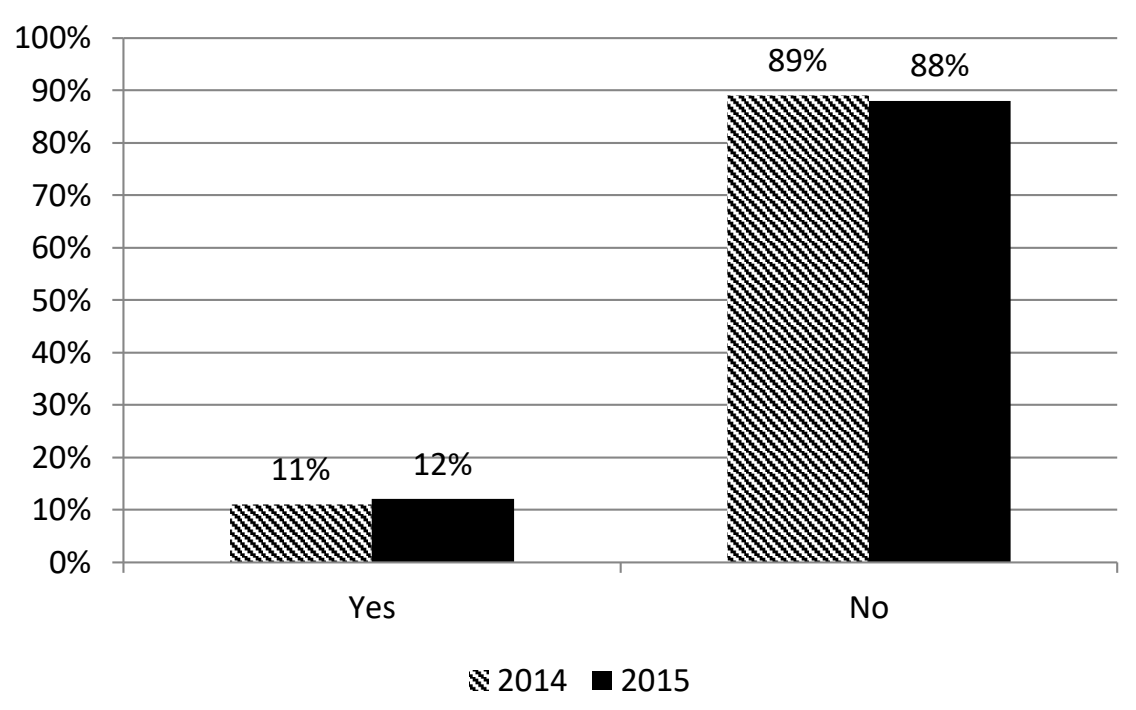

To summarize, drawing on data from two comprehensive surveys of Chinese investors in the United States, this section presents an empirical overview of how they perceive of and respond to the CFIUS process. According to the survey data, the majority of Chinese investors did not consider CFIUS when investing in the United States. For those that did consider CFIUS review, U.S. lawyers provided important legal guidance. In terms of their perception of the system, a significant minority of Chinese investors confessed to have no knowledge about CFIUS and hold no opinion. Among the rest, the majority considered CFIUS politicized and non-transparent. Finally, slightly more than $10 \%$ of the investors 
that had considered CFIUS had foregone at least some of their investments in the United States due to concerns with the review.

The data also reveals some interesting developments over time. First, more Chinese investors in the 2015 survey reported a positive view of CFIUS than in the prior survey. Second, more investors consulted U.S. lawyers over CFIUS matters in 2015 than in 2014. The Ralls decision likely influenced these changes. The ruling demonstrates that the agency and the President are bound by law, leaving Chinese investors with a positive impression of the lawfulness of the CFIUS process. It also educated investors about the importance of U.S. law, sending more investors to solicit legal advice.

The descriptive data, though informative, cannot fully reveal the effects of the potential multi-factors at work. For instance, to what extent does a Chinese investor's state ownership explain the perception and reaction to the CFIUS regime? How about the sensitivity of the sector to which the investor belongs? Size should matter as well, as it sets the expected payoffs from a potential CFIUS sanction. What exactly is the role of Ralls if other variables are controlled? The following subsection conducts statistical analysis to shed light on these questions.

\section{Regression Analysis}

Using data from the two annual surveys, this subsection statistically analyzes how the executives of the U.S. affiliates of China-based multinationals perceive and react to the CFIUS review process. I focus on three aspects central to the ongoing debate. First, I explore the factors associated with the Chinese investors' consideration of the CFIUS review. As noted, filing with CFIUS is optional. And it is not even in the interest of the agency to encourage parties to all covered transactions to file a notice prior to their investments. So, the key question is under what conditions are Chinese investors more likely to consider the option of notifying CFIUS when making their U.S. investments? Moreover, did the Ralls decision change the actual behavior of the Chinese investors as predicted? Second, I investigate the conditions under which the Chinese investors actually file a notice with CFIUS, and whether the Ralls decision has significantly impacted the filing behavior. Third, I examine the perception of the CFIUS process by the Chinese investors and how the Ralls decision has changed it.

\section{Considering CFIUS Review when Investing in the United States}

Filing with CFIUS prior to a covered transaction is voluntary. Foreign investors that do not file bear the risk of a CFIUS investigation and sanction if a threat to U.S. national security is later found. Under the current law, several factors theoretically raise such a risk. Foreign government ownership, for 


\section{Investing near the National Security Black Hole}

instance, triggers an automatic investigation by CFIUS if the agency is notified of the covered transaction. Foreign investments in sectors tied closely to national defense also raise red flags. Do these factors in practice shape the foreign investors' consideration of the CFIUS review? What are their independent effects? This subsection statistically examines these questions.

\section{a. Dependent Variable}

The dependent variable is a dummy that equals one if the survey respondent reported to have considered the CFIUS review when investing in the United States, zero if otherwise. As noted earlier, the majority of the respondents did not consider it when they invested in the United States (see Figure 5).

\section{b. Independent and Control Variables}

Chinese government ownership. The first independent variable of interest is the extent to which the Chinese government owns the U.S. business. Covered transactions that result in direct or indirect foreign government control raise a red flag in the CFIUS process. FINSA specifies that, when notified, CFIUS should automatically initiate an investigation of such covered transactions. However, a clear definition of foreign government control is lacking. Congress did not equate it to majority or whole government ownership in a U.S. business. CFIUS is authorized to examine all facts and circumstances of a covered transaction in determining whether it will result in foreign government control. The vague and ambiguous language causes more problems for Chinese investors intending to enter the U.S. market via mergers and acquisitions, because the visible hand of the Chinese government exerts a powerful influence over Chinese companies, either directly through equity ownership or indirectly through highly intervening rules and policies.

To operationalize the concept, I use a dummy variable that equals one if a Chinese government entity controls at least $50 \%$ of the equity interest of an investor. The majority ownership provides for clear state domination in the Chinese investor. Some scholars, however, have contended that majority state ownership is not a necessary condition for the Chinese government to exert control or influence. ${ }^{107}$ Thus, I create an alternative dummy variable that equals one if Chinese government entities own more than $10 \%$ of the equity interest of a Chinese investor, zero otherwise. I draw the line at $10 \%$, a conventional threshold in major regulatory areas, to separate companies with state ownership from essentially private Chinese companies. I will use the two dummies $(50 \%$ state ownership and $10 \%$ state ownership) alternately in the regression tests to fully assess the effect of Chinese government ownership.

107. Curtis Milhaupt \& Wentong Zheng, Beyond Ownership: State Capitalism and the Chinese Firm, 103 GEO. L.J. 665 (2015). 


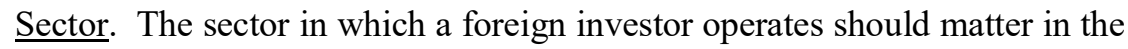
consideration of CFIUS review. First of all, sectoral distribution may be correlated with Chinese investors' ownership structures because under the current Chinese laws and policies, government-owned enterprises tend to occupy strategically important sectors in China. ${ }^{108}$ Second, some sectors have close ties to national security. For instance, covered transactions targeting critical U.S. infrastructure has been singled out to automatically trigger a CFIUS investigation upon receiving a notice. ${ }^{109}$ Similarly, CFIUS has frequently investigated foreign investments in telecommunications. ${ }^{110}$ Though Congress refuses to provide a clear definition of national security, it offers a list of considerations for the CFIUS analysis, which closely relate to a foreign acquirer's sector. I create a dummy that equals one if the foreign investor operates in a "sensitive sector," zero otherwise. The tricky issue in coding for this variable is how to define "sensitive sector" when the formal definition remains ambiguous. Based on the enumerated factors in the regulations and prior research, I define the term broadly to include critical infrastructure, critical information technology (especially in telecommunications), transportation, heavy machinery with dual use potential, public utilities, and military industry.

Size of investment. How much a foreign investor invests in the United States should affect the expected payoffs from a CFIUS investigation and sanction. The amount should also correlate with the investor's ability to bear the cost of CFIUS filing and subsequent litigation if necessary. The surveys inquired about the dollar amounts of the responding companies' assets in the United States. For the regression tests, I use the logarithmic values of the reported asset amounts. Adding this variable, however, reduces the sample size, as some respondents were reluctant to disclose the information (see Table 1).

Greenfield investment. The current law excludes greenfield investments from CFIUS review. Foreign investors that build business operations from scratch do not pose, in the eyes of Congress, any national security threat that cannot be addressed by other U.S. laws. ${ }^{111}$ To account for the variation in the mode of investment, I add a dummy variable that equals one if the Chinese investor has previously engaged in a merger or acquisition in the United States, zero otherwise.

Duration of investment. For the following reasons, the statistical tests include, as a control, the duration of a company's operation in the United States. First, it may have some confounding effect if Chinese investors, having operated

108. Boy LÜthje et AL., Beyond the Iron Rice Bowl: Regimes of Production AND INDUSTRIAL RELATIONS IN CHINA (2013).

109. 31 C.F.R. $\S 800.503(\mathrm{~b})(2)(2011)$.

110. For instance, the Chinese telecommunications company, Huawei, has been investigated several times by CFIUS and its acquisitions of U.S. business have been prohibited. See Li, supra note 65, at 143 .

111. See 31 C.F.R. $\S 800.301$ (c) (2011) (example 3 illustrates this point). 


\section{Investing near the National Security Black Hole}

in the United States for an extended period (many of them state-owned), have fully internalized, or grown accustomed to, the complex CFIUS rules. Second, investment duration may offer some hints about potential survival bias. Chinese investors that experience major CFIUS issues may withdraw from the U.S. market earlier than others. The former would be absent from the sample, resulting in a sampling bias. Third, as noted earlier, duration of investment is essential to the calculation of expected payoffs relating to the CFIUS filing.

Year of survey. The surveys took place in 2014 and 2015. In the summer of 2014 , most of the survey questionnaires had been completed and collected before the D.C. Circuit decided Ralls on July 15, 2014. So for most of the respondents, the surveys reflected their knowledge, if any, about the trial court decision, which dismissed all of Ralls's claims, and the generally-shared expectation that the D.C. Circuit would uphold the lower court's decision. When the 2015 survey was conducted, Ralls had won the lawsuit against CFIUS and the President, and the case had been remanded to the District Court for a full trial on several open issues. I add a survey year dummy to catch the effect of the Ralls decision. The dummy equals one if the data is collected from the 2014 survey, two if from the 2015 survey.

U.S. business ownership. Ownership in a U.S. business matters in terms of the foreign investors' national security threat. A prior study shows that stateowned enterprises strategically invest through joint ventures to reduce political risk. ${ }^{112}$ Moreover, CFIUS considered having U.S. citizens managing the U.S. assets as a key mitigating factor for national security risk. ${ }^{113}$ The factor should also affect the consideration by Chinese investors as it discounts the expected payoffs. According to the survey data, most of the Chinese investors invest through wholly owned subsidiaries, instead of joint ventures or minority equity ownership.

112. Lin Cui \& Fuming Jiang, FDI Entry Mode Choice of Chinese Firms: A Strategic Behavior Perspective, 44 J. OF WORLD BUS. 434 (2009).

113. Zaring, supra note 6 , at 81 . 
Table 1: Summary Statistics of the Variables

\begin{tabular}{|cccccc|}
\hline Variable & Mean & Std. Dev. & Min & Max & Observations \\
\hline Considered CFIUS & .4191617 & .4949059 & 0 & 1 & 167 \\
\hline State Ownership (50\%) & .4846939 & .5010455 & 0 & 1 & 196 \\
\hline State Ownership (10\%) & .5663265 & .4968504 & 0 & 1 & 196 \\
\hline Years of Operation in US & 13.06566 & 9.755942 & 1 & 40 & 198 \\
\hline Log US Assets & 7.454977 & 2.507044 & .59 & 15.98 & 114 \\
\hline US Business Ownership & .8449198 & .3629529 & 0 & 1 & 187 \\
\hline Investment Mode & .3370166 & .4740018 & 0 & 1 & 181 \\
\hline Sector of Business & .2427184 & .4297707 & 0 & 1 & 167 \\
\hline Filed Notice with CFIUS & .0958084 & .29252135 & 0 & 1 & \\
\hline
\end{tabular}

The first set of tests examines the general action of considering CFIUS during a foreign investment in the United States. Table 2 below reports different model specifications where the dependent variable is whether the Chinese investor considered the CFIUS review when making its investment in the United States. I run logit tests, with the coefficients reporting odds ratio. For example, in Column 4, the odds ratio for the independent variable "state ownership" is 2.61 , meaning that, everything else equal, an investor who was majority-owned by a Chinese government entity was $161 \%$ more likely than privately-owned or minority-state-owned investors to have considered CFIUS review when investing in the United States.

The sector in which the Chinese investor operates is also significant. For those doing business in sensitive sectors, the odds ratio is as high as 5.31, indicating that those investors are $431 \%$ more likely than investors in nonsensitive sectors to have considered CFIUS review when investing in the United States. Moreover, the Chinese investor's investment size as measured by its U.S. business is also highly significant. Those with larger investments tend to be more likely to consider CFIUS review when investing in the United States. 


\section{Investing near the National Security Black Hole}

Table 2: Regression Results (dependent variable: respondent considered CFIUS when investing)

\begin{tabular}{cccccc}
\hline & $\mathbf{( 1 )}$ & $\mathbf{( 2 )}$ & $\mathbf{( 3 )}$ & $\mathbf{( 4 )}$ & $\mathbf{( 5 )}$ \\
\hline State Ownership & $3.088^{* * *}$ & $2.862 * * *$ & $2.635 * *$ & $2.609 *$ & \\
$(>\mathbf{5 0 \%})$ & $(1.153)$ & $(1.15)$ & $(1.124)$ & $(1.431)$ & \\
State Ownership & & & & & 2.09 \\
$(>\mathbf{1 0 \%})$ & & & & & $(1.17)$ \\
Sector of Business & $3.425 * * *$ & $3.321 * * *$ & $3.573 * * *$ & $5.306 * * *$ & $5.249 * * *$ \\
& $(1.502)$ & $(1.504)$ & $(1.685)$ & $(3.277)$ & $(3.317)$ \\
Years of Operation & & 0.992 & 0.994 & 1.012 & 1.016 \\
in US & & $(0.02)$ & $(0.021)$ & $(0.028)$ & $(0.028)$ \\
US Business & & 1.292 & 1.324 & 0.788 & 0.764 \\
Ownership & & $(0.71)$ & $(0.768)$ & $(0.584)$ & $(0.56)$ \\
Investment Mode & & & $2.658 * *$ & 1.262 & 1.258 \\
US Assets (log) & & & $(1.057)$ & $(0.713)$ & $(0.712)$ \\
& & & & $1.394 * *$ & $1.38 * *$ \\
Survey Year & & & & $(0.197)$ & $(0.194)$ \\
& & & & 1.268 & 1.289 \\
$\mathbf{N}$ & 160 & 147 & 138 & $9.685)$ & $(0.69)$ \\
\hline
\end{tabular}

Note: ${ }^{* * *} \mathrm{p}<0.01 ;{ }^{*} \mathrm{p}<0.05 ;{ }^{*} \mathrm{p}<0.1$; odds ratio reported.

These empirical findings are highly consistent with what one predicts rational foreign investors would do in response to the formal CFIUS rules. The DPA, as amended by FINSA, specifically provides that CFIUS investigate covered transactions resulting in foreign government control of U.S. assets, and investment in sensitive sectors such as critical infrastructure receive heightened scrutiny of the agency. Thus, these two variables directly affect the probability of a CFIUS investigation and sanction. On the other hand, the size of investment determines the payoffs calculated by the investors. According to the decision tree, it is evident that foreign investors should carefully consider CFIUS review before they make substantial investments with long-term returns, as CFIUS investigation may result in a divestiture order. In other words, foreign investors intending to acquire substantial U.S. assets cannot afford to be "rationally ignorant" about the CFIUS review.

Other variables are not significant in all the model specifications. Duration of investment, for instance, does not appear to affect the consideration of CFIUS review. Presumably, Chinese companies that have operated in the United States for a long term should constitute less of a national security threat, otherwise they would have already caught the attention of CFIUS and been ordered to divest. So, one might have expected the odds ratio to be significant and less than one. The finding that the variable is insignificant when other variables are included in the regression suggests that duration itself may not be the crucial factor. For instance, a private Chinese company in a non-sensitive sector (e.g., textile), 
regardless of how long it has operated in the United States, would have no incentive to consider CFIUS review when acquiring U.S. businesses in its sector.

Additionally, U.S. business ownership is insignificant. Prior studies have shown that CFIUS considered the threat to U.S. national security to be less acute if American citizens participate in certain managing activities. ${ }^{114}$ Yet according to the regression result, whether the Chinese investor wholly owns its U.S. business or has a local partner does not appear to affect whether it considers CFIUS review.

Somewhat surprisingly, whether a Chinese investor enters the U.S. market through mergers and acquisitions is not significant in all the model specifications when other variables such as investment size, sectoral sensitivity, and state ownership are controlled. A possible explanation is that when a Chinese investor invests a substantial amount in the United States, even if, in the mode of a greenfield investment, the investor will nonetheless consider the consequence of potential CFIUS review. This makes sense if one can appreciate the blurry line between a greenfield investment and a covered transaction. ${ }^{15}$ When an investment reaches a certain scale, it is almost impossible for the foreign investor not to engage in some covered transactions, even though the intent is to build a business operation from scratch. Take the investment in Ralls as an example. The Chinese investors acquired U.S. companies with the intent to use the land they owned in Oregon to build wind farms. This is in essence a greenfield investment. However, because they purchased the U.S. firms that owned the land, the investment falls under the definition of covered transaction. Had an individual owned the same land, and Ralls purchased the land directly from the individual, the investment would not have been a covered transaction, thus not be subject to CFIUS review. Given the shifting boundary between greenfield investments and covered transactions, a rational investor should take into account CFIUS review when substantial interest is at stake. This, however, is speculative. Given the limited sample size, one should refrain from drawing definitive inference from the non-significant coefficient.

Finally, the Ralls decision by the D.C. Circuit does not appear to have any significant impact on whether Chinese investors would consider CFIUS review. One may attribute it to a lagging effect. By the time the 2015 survey was administered, the investors had not fully grasped the decision's effects on CFIUS's actions. Yet another plausible explanation is that when other variables such as state ownership and investment size are controlled, Chinese investors do not expect the Ralls decision to substantially alter the payoffs regarding the CFIUS process. After all, CFIUS still enjoys wide discretion despite the due process requirement imposed by the D.C. Circuit. ${ }^{116}$

114. Id.

115. Fernandez, supra note 17, at 44.

116. Li, supra note 65 , at 143 . 


\section{Investing near the National Security Black Hole}

I also test the effect of Chinese government control using the alternative measure that broadens the concept. The dummy variable (one if a Chinese government entity owns more than $10 \%$ of the investor) is not significant anymore. The preliminary finding suggests that majority government ownership in a Chinese multinational differs qualitatively from minority state ownership. I also run separate tests using the survey data of each year. Though some coefficients are no longer significant due to the much smaller sample size, the results are not substantially different from those of the pooled sample.

In sum, the results from the regression analysis confirmed some predictions and dispelled others about Chinese investors' consideration of CFIUS when investing in the United States. To be more concrete, the findings render support to the hypothetical link between significant state ownership in Chinese investors and their consideration of CFIUS review. Also, there is preliminary evidence that those contemplating investment in sensitive sectors are more likely to consider CFIUS review, and Chinese investors who invest substantial amounts are more inclined to take CFIUS into account. Other potential variables (e.g., investment duration and U.S. business ownership) are not significant in all of the model specifications, though definitive conclusions cannot be drawn at this moment due to limited sample size.

\section{Size and Sector: The Most Important Factors for Filing with the CFIUS}

As discussed earlier, foreign investors file a notice with CFIUS to seek a safe harbor for its U.S. investment. Who among the Chinese investors in the United States will not only consider CFIUS review but will also eventually file the notice? This subsection statistically analyzes that question.

For this set of tests, the dependent variable is a dummy that equals one if the Chinese respondent had filed a notice with CFIUS when investing in the United States. Because the calculation for the filing is essentially identical to that for considering the CFIUS process, I used the same independent and control variables as those in the preceding subsection. Because the dependent variable is binary, I ran logit tests on the data. 
Table 3: Regression Results (dependent variable: respondent filed with CFIUS when investing)

\begin{tabular}{ccccc}
\hline & $(\mathbf{1})$ & $(\mathbf{2})$ & $\mathbf{( 3 )}$ & $(\mathbf{4})$ \\
\hline State Ownership (>50\%) & 1.211 & 3.061 & 2.144 & \\
State Ownership (>10\%) & $(0.855)$ & $(2.743)$ & $(1.958)$ & \\
& & & & 3.09 \\
Sector of Business & $9.146^{* * * *}$ & $6.743 * *$ & $7.841^{* *}$ & $6.351^{* * *}$ \\
& $(6.206)$ & $(5.683)$ & $(7.117)$ & $(5.93)$ \\
Years of Operation in US & 0.951 & 0.935 & 0.938 & 0.936 \\
& $(0.03)$ & $(0.04)$ & $(0.041)$ & $(0.041)$ \\
US Business Ownership & & 0.483 & 0.435 & 0.411 \\
& & $(0.421)$ & $(0.409)$ & $(0.39)$ \\
Investment Mode & & & 3.474 & 3.045 \\
& & & $(3.028)$ & $(2.707)$ \\
US Assets (log) & & $1.682^{* * *}$ & $1.551 * *$ & $1.60 * *$ \\
& & $(0.337)$ & $(0.339)$ & $(0.367)$ \\
Survey Year & & 1.305 & 1.474 & 1.50 \\
& & $(1.167)$ & $(1.347)$ & $(1.369)$ \\
\hline
\end{tabular}

Note: ${ }^{* * *} \mathrm{p}<0.01 ; * * \mathrm{p}<0.05 ;{ }^{*} \mathrm{p}<0.1$; odds ratio reported.

Table 3 shows the results from different model specifications. For example, in Column 3, the Chinese investor's sectoral background continues to be a significant predictor of the filing with CFIUS. The odds ratio is as high as 7.84, indicating that, everything else held constant, investments in sensitive sectors significantly increase the odds of filing a CFIUS notice relative to investments outside those sectors. This finding confirms what we expect of a rational foreign investor.

Similarly, Chinese investors with larger investment assets in the U.S. are more likely to have filed a CFIUS notice for their investments. As shown in Figure 3 (the decision tree), investment size enters into the calculation of the expected payoffs. The more investment a Chinese company makes in the United States, the more it will benefit from obtaining safe harbor protection in the form of a CFIUS approval.

Surprisingly, Chinese government ownership in the investor is no longer significant. There are several possible explanations. First, even though foreign government ownership may raise the likelihood of a CFIUS investigation, the factor per se will not result in sanctions. So, after controlling for sectoral sensitivity and asset size, Chinese government ownership is not significant. Take, for example, a textile manufacturer owned by a Chinese government 


\section{Investing near the National Security Black Hole}

entity. The management planning to acquire a U.S. peer company reasonably expects the risk of a CFIUS finding of national security threat to be minimal. Thus, the Chinese investor, despite its government ownership, will feel comfortable skipping the filing. Another possible explanation is that some stateowned investors consider the probability of CFIUS rejection or sanction so high that they give up certain acquisitions. The survey data indicates that any company that has ever abandoned a U.S. business merger or acquisition due to CFIUS concerns is at least majority-owned by the Chinese government. In addition, readers should keep in mind that due to the limited sample size, the lack of significance cannot be conclusive evidence of no association.

Again, U.S. business ownership is not significant. Having a local partner is not associated with any major change in the Chinese investor's propensity to file a notice with CFIUS, although one factor CFIUS typically considers to determine a covered transaction is how a joint venture is formed. ${ }^{117}$

Survey year is not significant, indicating that Ralls did not change the filing behavior of the Chinese investors. As discussed earlier, many other factors may affect the expected payoff sum, even though the D.C. Circuit decision has the potential to alter the payoffs in such a way that, everything else equal, investors are more incentivized not to file a notice with CFIUS prior to embarking on a covered transaction. CFIUS can react accordingly to offset the changes due to Ralls. Moreover, given the cost and uncertainty of litigation, the additional constitutional protection should affect the decision only on the margin, so it is not surprising that the Chinese investors discount the benefits.

In sum, when it comes to filing notices with CFIUS, investment size and sectoral sensitivity play significant roles. The findings are consistent with the expectations derived from the rational decision-making model. State ownership is not significant. But it is premature to draw definitive conclusions from the finding, as it could mean either that government ownership per se is unimportant for filing decisions or that state-owned companies have self-selected out of sensitive investments that require CFIUS filings.

\section{Additional Judicial Scrutiny Aids Perception of the CFIUS Process}

As shown by the descriptive data, Chinese investors hold a rather mixed view of the CFIUS process. This subsection analyzes how the perception varies across time and in accordance with changes on other dimensions. I hypothesize that those specifically targeted by CFIUS will be less likely to see the review process positively. In addition, everything else held constant, the surprising ruling in Ralls may have significantly changed the view about the CFIUS process.

I create a dummy dependent variable that equals one if the respondent considers the CFIUS review process to be transparent and in accordance with the

117. 31 C.F.R. $\S 800.301(d)(2011)$. 
law, zero otherwise. I use the same set of independent and control variables as in the previous sections. Because the dependent variable is binary, I run logit tests to assess the hypotheses. Table 4 displays regression results from different model specifications.

For example, consider the data from Column 3. First, state ownership is significant. The odds ratio is 0.159 , indicating that, all else being equal, Chinese companies majority-held by a government entity are $84.1 \%$ less likely than those with other ownership characters to consider the CFIUS review process as transparent and undertaken in accordance with the law. This is not surprising. As noted earlier, foreign government control triggers CFIUS investigation automatically after notice, irrespective of the substantial threat to U.S. national security. Such categorical agency response inevitably results in the perception of arbitrariness and the lack of transparency. As noted, much of the review's opaqueness is due to the tension between economic integration and political distance between China and the United States. While the world's two titans are moving ever closer in trade and investment, their political objectives diverge on many aspects. ${ }^{118}$ Many in the United States consider the Chinese government a rising contender of global leadership potentially disrupting the existing international order; ${ }^{19}$ Chinese elites cannot help but interpret U.S. foreign policies as aimed at maintaining its leadership by containing and stalling China's legitimate rise in the world. ${ }^{120}$ Against this backdrop, key institutions in the U.S. government inevitably treat Chinese state-owned enterprises differently from other foreign companies based in ally countries such as Japan and Canada. ${ }^{121}$ Yet the differentiation cannot be openly stated, as it would negatively implicate the diplomatic relations with China and contradict other long-held U.S. policies such as welcoming foreign investment and non-discrimination. The maintenance of a "superficial friendship" by the governments greatly adds to the uncertainties of the CFIUS process for Chinese state-owned investors. ${ }^{122}$

118. See, e.g., Xuetong Yan, The Instability of China-US Relations, 3 CHINESE J. OF INT'L POL. 263 (2010).

119. David N. Fagan, The US Regulatory and Institutional Framework for FDI, in INVESTING THE UNITED STATES: IS THE US READY FOR FDI FROM CHINA 3 (Karl P. Sauvant ed., 2009).

120. Id.

121. Id. The suspicion of investments from Chinese SOEs may materialize in the CFIUS process as concerns with espionage risk. See also Connell \& Huang, supra note 59, at 135.

122. Yan, supra note 118, at 263. 


\section{Investing near the National Security Black Hole}

Table 4: Regression Results (dependent variable: respondent considered CFIUS transparent and in accordance with the law)

\begin{tabular}{|c|c|c|c|c|c|}
\hline & (1) & (2) & (3) & (4) & (5) \\
\hline $\begin{array}{c}\text { State Ownership } \\
(>\mathbf{5 0 \%})\end{array}$ & $\begin{array}{l}0.263 * * \\
(0.147)\end{array}$ & $\begin{array}{l}0.258 * * \\
(0.154)\end{array}$ & $\begin{array}{l}0.159 * * \\
(0.143)\end{array}$ & $\begin{array}{c}0.165 * * \\
0.146)\end{array}$ & \\
\hline $\begin{array}{c}\text { State Ownership } \\
(>10 \%)\end{array}$ & & & & & $\begin{array}{c}0.449 \\
(0.342)\end{array}$ \\
\hline Sector of Business & $\begin{array}{c}1.393 \\
(0.841)\end{array}$ & $\begin{array}{c}1.444 \\
(0.953)\end{array}$ & $\begin{array}{c}2.231 \\
(2.055)\end{array}$ & $\begin{array}{l}2.239 \\
(2.062)\end{array}$ & $\begin{array}{c}1.346 \\
(1.168)\end{array}$ \\
\hline $\begin{array}{c}\text { Years of Operation in } \\
\text { US }\end{array}$ & & $\begin{array}{c}0.966 \\
(0.029)\end{array}$ & $\begin{array}{c}0.968 \\
(0.038)\end{array}$ & $\begin{array}{c}0.967 \\
(0.038)\end{array}$ & $\begin{array}{c}0.959 \\
(0.036)\end{array}$ \\
\hline $\begin{array}{l}\text { US Business } \\
\text { Ownership }\end{array}$ & & & $\begin{array}{c}1.343 \\
(1.314)\end{array}$ & $\begin{array}{l}1.321 \\
(1.295)\end{array}$ & $\begin{array}{l}1.52 \\
(1.466)\end{array}$ \\
\hline Investment Mode & & & $\begin{array}{l}1.125 \\
(0.826)\end{array}$ & & $\begin{array}{c}1.053 \\
(0.766)\end{array}$ \\
\hline US Assets (log) & & & $\begin{array}{l}1.663 * * \\
(0.383)\end{array}$ & $\begin{array}{l}1.712 * * \\
(0.385)\end{array}$ & $\begin{array}{l}1.654 * * \\
(0.374)\end{array}$ \\
\hline Survey Year & & $\begin{array}{l}4.121 * * \\
(2.284)\end{array}$ & $\begin{array}{c}15.011 * * * \\
(15.184)\end{array}$ & $\begin{array}{c}14.796 * * * \\
(15.155)\end{array}$ & $\begin{array}{l}12.41 * * * \\
(11.897)\end{array}$ \\
\hline Legal Advice & & & & $\begin{array}{l}0.855 \\
(0.71)\end{array}$ & \\
\hline $\mathbf{N}$ & 145 & 140 & 85 & 86 & 85 \\
\hline
\end{tabular}

Note: ${ }^{* * *} \mathrm{p}<0.01 ;{ }^{*} \mathrm{p}<0.05 ;{ }^{*} \mathrm{p}<0.1$; odds ratio reported.

In addition, investment size matters. The odds ratio is 1.663 , so Chinese investors with larger U.S. investments are more likely to consider CFIUS review transparent and bound by the law. Why would the group of Chinese investors more frequently scrutinized by CFIUS consider the process transparent and lawful? One plausible explanation is that larger companies have the resources to hire experts of the CFIUS bar and therefore have access to the insiders' information. Aided by their expertise, the investors consider the process more predictable and transparent. Anecdotal media reports appear to support this hypothesis. However, the results in Column 5 show that adding the variable of legal assistance to the regression does not make any measurable difference, and asset size remains highly significant. An alternative explanation is that public media, especially the Chinese media, has portrayed the CFIUS system too negatively, so that actual interactions with the agency and the process somewhat ameliorate the negative perception. As companies with larger assets are more likely to interact with CFIUS, their experiences may help correct the perception, unless these companies are controlled by a Chinese government entity. ${ }^{123}$

123. The result may also indirectly reflect the high correlation between the investors' awareness of CFIUS review and the size of their U.S. investments. The sample excluding the observations of no CFIUS 
Moreover, the survey year is also significant, and the odds ratio is as high as 15.01, indicating that everything else equal, a Chinese investor's perception of CFIUS in 2015 is much more likely to be positive than it was in 2014. As noted, the major change between the two survey years is the surprising Ralls decision by the D.C. Circuit in favor of the Chinese investor. The result strongly indicates that the widely publicized case has substantially improved the view of Chinese investors about the CFIUS process.

In contrast to the findings of the preceding two tests, sectoral sensitivity is not significantly associated with the probability of a positive perception of the CFIUS system, after controlling for the other variables. Though related, the perception of CFIUS is a step away from the payoff calculations. ${ }^{124}$ In addition, investment duration is not significantly tied to the probability of viewing the CFIUS system as transparent and lawful; nor is U.S. business ownership significant. Given the sample size, however, no definitive conclusion can be drawn from the finding of no significance.

\section{CONTRIBUTIONS AND LIMITATIONS}

The article presents the first study of the CFIUS regime from the viewpoint of foreign investors. The findings contribute to the literature in multiple ways. First and foremost, the article presents much-needed information about foreign investors' perception of and reaction to the CFIUS process. As noted, prior research has centered on the legal and political aspects of CFIUS, totally ignoring the receiving end of the review mechanism. This article narrows the gap.

Second, the debate about the regime's efficacy has thus far hinged on an educated guess. Although integrated annual data publicized by CFIUS and anecdotal reports shed some light on foreign investors' reactions to the review, the topic lacks systematic study. The "silent majority," those that invest without filing a CFIUS notice or with their notices approved, do not appear in any archival data. This study presents such information in a systematic way.

Third, scholars as well as practitioners have paid much attention to the surprising decision by the D.C. Circuit in Ralls $v$. CFIUS. While some speculate that the case may offer some clarity to the CFIUS process, ${ }^{125}$ others downplay the significance of the decision regarding its practical impact. ${ }^{126}$ This study weighs in on this debate. The findings suggest that the decision significantly

knowledge is very small in size, so tests of this possible explanation are better done after more data is collected.

124. The simple correlation between having any knowledge of CFIUS and its consideration is $49 \%$.

125. See, e.g., Anne W. Salladin \& Amelia J. Schmidt, CFIUS Post-Ralls: Ramifications for Sovereign Wealth Funds, INT'L REV. OF L. 1, 21 (2015).

126. Charles A. Blanchard, et al., Will Ralls Decision Really Bring CFIUS Transparency?, Law360 (Aug. 12, 2014), http://www.law360.com/articles/566033/will-ralls-decision-really-bring-cfiustransparency. 


\section{Investing near the National Security Black Hole}

altered the perception of Chinese investors of the CFIUS process. Yet there is not sufficient evidence that the case has changed the investors' actual behavior.

Fourth, the study also contributes to the debate about Chinese investment in the United States. As an important institution intended to safeguard U.S. national security, the CFIUS review process sets a hurdle for Chinese investments. Public media has portrayed it as a serious barrier that dampens foreign investment. On the other hand, the U.S. government has emphasized the narrow coverage of the CFIUS review and its longstanding policy to welcome foreign investment. According to the findings of this study, sizable Chinese investors in the United States react to CFIUS in a largely rational manner, and there is preliminary evidence of deterrence effect. However, whether the deterrence is efficient awaits future inquiry.

Although the study, compared to anecdotal analysis, is a major step forward in the research about CFIUS and foreign investment, it has several drawbacks. First, the sample is relatively small, so definitive conclusions cannot be drawn from the findings of no-significance. Second, the sample restrains the study to Chinese investors already operating in the United States. The data does not allow me to analyze the impact of CFIUS on Chinese companies that have yet to invest in the United States. In other words, to know the full effect of CFIUS globally, future research has to survey a sample of all Chinese companies that have invested or have considered investing in the United States. Despite the limited scope, valid inferences can be drawn from the findings of this study. Given the over-representation of state-owned enterprises and companies in sensitive sectors in this sample, the data very likely provides the upper or lower bounds of the range of possible ratios. In short, the findings of this study provide an important update of our knowledge about FDI and the national security review regime in the United States.

\section{CONCLUSION}

The expansion of investment by multinational corporations gives rise to growing frictions with some core interests of sovereign governments. This article empirically explores the conflicts in its most manifested case, i.e., direct investments by China-based multinationals and the CFIUS regime. I find that, contrary to popular belief, many Chinese investors are largely uninformed about the system and skip the filing for CFIUS review when investing in the United States. The majority of those who have knowledge of CFIUS consider the review process politicized and non-transparent, and a minority report to have abandoned their investments due to concerns with CFIUS. Variations in the perception and the reactions of the Chinese investors generally hinge on their government ownership, sectoral sensitivity, and the size of their U.S. investments. Moreover, the study finds that even though the recent landmark decision in Ralls v. CFIUS had a significant impact on the investors' perception of the system, the case has 
not altered their filing behavior. The study fills a major gap in the literature and contributes to the ongoing debate about the optimal balance between preserving an open investment market and protecting U.S. national security in light of surging direct investment from countries that are not considered U.S. allies. 